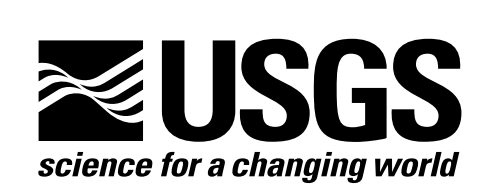

\title{
Updated Computations and Estimates of Streamflows Tributary to Carson Valley, Douglas County, Nevada, and Alpine County, California, 1990-2002
}

Scientific Investigations Report 2004-5179

Prepared in cooperation with DOUGLAS COUNTY

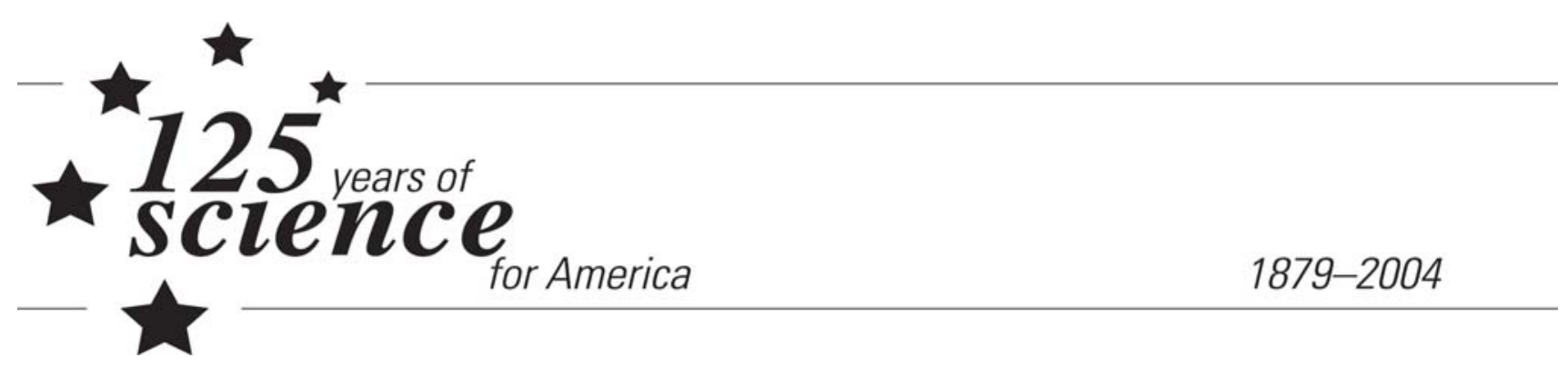


(Back of Cover) 


\section{Updated Computations and Estimates of Streamflows Tributary to Carson Valley, Douglas County, Nevada, and Alpine County, California, 1990-2002}

by Douglas K. Maurer, Sharon A. Watkins, and Robert L. Burrows

U.S. GEOLOGICAL SURVEY

Scientific Investigations Report 2004-5179

Prepared in cooperation with

DOUGLAS COUNTY 


\title{
U.S. DEPARTMENT OF THE INTERIOR \\ GALE A. NORTON, Secretary
}

\author{
U.S. GEOLOGICAL SURVEY \\ CHARLES G. GROAT, Director
}

Any use of trade, product, or firm names in this publication is for descriptive purposes only and does not imply endorsement by the U.S. Government

For additional information contact:

District Chief

U.S. Geological Survey 333 West Nye Lane, Room 203

Carson City, NV 89706-0866

email: GS-W-NVpublic-info @ usgs.gov

http://nevada.usgs.gov
Copies of this report can be purchased from:

U.S. Geological Survey

Information Services

Building 810

Box 25286, Federal Center

Denver, CO 80225-0286 


\section{CONTENTS}

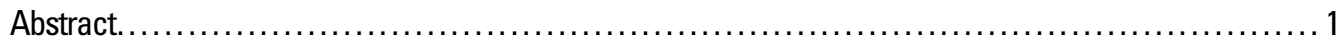

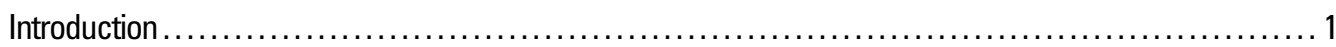

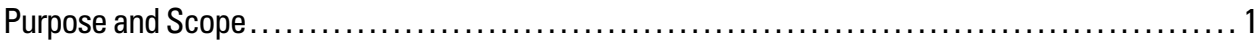

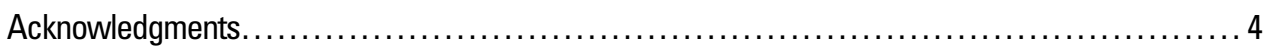

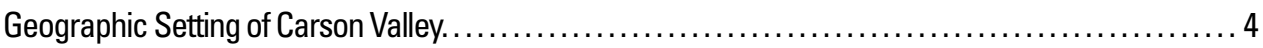

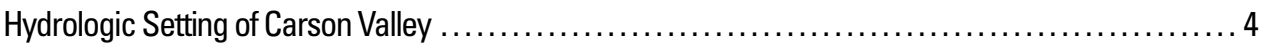

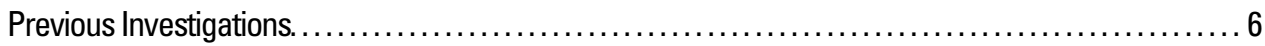

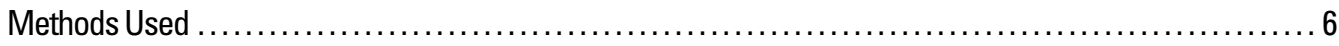

Updated Computations and Estimates of Streamflows Tributary to Carson Valley ..................... 15

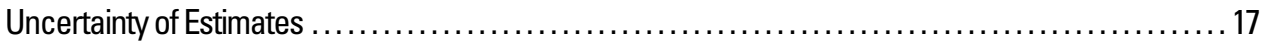

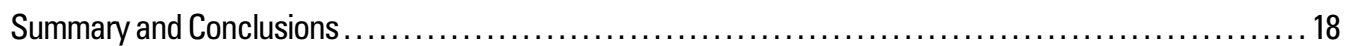

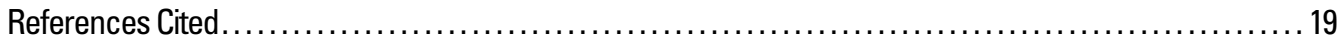

Appendix Graphs showing computed and estimated mean monthly flow for gaged and

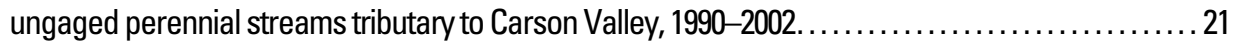

\section{FIGURES}

1. Map showing locations of Carson River Basin and Carson Valley Hydrographic Areas............2

2. Map showing location of surface-water sites used for this study, Carson Valley subarea and study area, and physiographic features of Carson Valley ............................

3. Map showing location of surface-water sites used for delineation of boundaries in previous studies, Carson Valley subarea and study area, and physiographic features of Carson Valley......5

4. Scatter plots of measured and simulated flows for $(A)$ Water Canyon Creek and

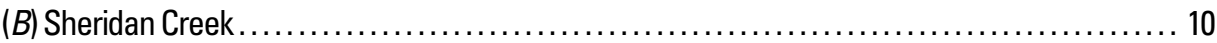

5. Graphs showing estimated daily mean flow and periodic measurements of flow for ungaged perennial drainages, 1990-2002

6. Graphs showing computed and estimated mean annual flow for gaged and ungaged perennial streams tributary to Carson Valley, 1990-2002.

7. Graphs showing $(A)$ annual flow of the East Fork Carson River near Gardnerville, Nevada, and average annual flow for 1939-2002 and 1990-2002 and (B) annual precipitation at Minden, Nevada, for period of record and average annual precipitation for 1971-2000 and 1990-2002 .

\section{TABLES}

1. Site identifier information, period of record, and drainage area for surface-water sites

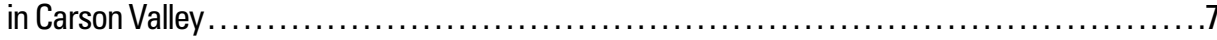

2. Regression model equations, $R^{2}$ values, percent error, and number of measurements

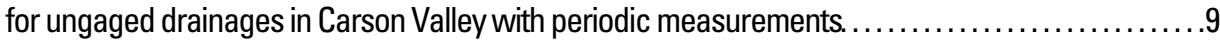

3. Computed and estimated mean annual flow of gaged and ungaged perennial streams and ephemeral drainages tributary to Carson Valley, 1990-2002, mean annual flow for period of record at gaged sites, annual flow estimated by Maurer (1986), drainage area, and unit-area flow. 


\section{CONVERSION FACTORS AND VERTICAL DATUM}

\begin{tabular}{rcl}
\hline Multiply & By & To obtain \\
& & \\
acre & 4,047 & square meter $\left(\mathrm{m}^{2}\right)$ \\
acre & 0.4047 & hectare $(\mathrm{ha})$ \\
acre-foot per year (acre- $\mathrm{ft} / \mathrm{rr})$ & 1,233 & cubic meter per year $\left(\mathrm{m}^{3} / \mathrm{yr}\right)$ \\
cubic foot per second $\left(\mathrm{ft}^{3} / \mathrm{s}\right)$ & 0.02832 & cubic meter per second $\left(\mathrm{m}^{3} / \mathrm{s}\right)$ \\
foot $(\mathrm{ft})$ & 0.3048 & meter $(\mathrm{m})$ \\
inch $(\mathrm{in})$. & 25.4 & millimeter $(\mathrm{mm})$ \\
inch per year $(\mathrm{in} / \mathrm{/r})$ & 25.4 & millimeter per year $(\mathrm{mm} / \mathrm{yr})$ \\
mile $(\mathrm{mi})$ & 1.609 & kilometer $(\mathrm{km})$ \\
square mile $\left(\mathrm{mi}^{2}\right)$ & 2.590 & square kilometer $\left(\mathrm{km}^{2}\right)$ \\
& &
\end{tabular}

Temperature: Degrees Celsius $\left({ }^{\circ} \mathrm{C}\right)$ can be converted to degrees Fahrenheit $\left({ }^{\circ} \mathrm{F}\right)$ by using the formula ${ }^{\circ} \mathrm{F}=\left[1.8\left({ }^{\circ} \mathrm{C}\right)\right]+32$. Degrees Fahrenheit can be converted to degrees Celsius by using the formula ${ }^{\circ} \mathrm{C}=0.556\left({ }^{\circ} \mathrm{F}-32\right.$.

Sea level: In this report, "sea level" refers to the National Geodetic Vertical Datum of 1929 (NGVD of 1929, formerly called "Sea-Level Datum of 1929"), which is derived from a general adjustment of the first-order leveling networks of the United States and Canada. 


\title{
Updated Computations and Estimates of Streamflows Tributary to Carson Valley, Douglas County, Nevada, and Alpine County, California, 1990-2002
}

\author{
by Douglas K. Maurer, Sharon A. Watkins, and Robert L. Burrows
}

\section{ABSTRACT}

Rapid population growth in Carson Valley has caused concern over the continued availability of water resources to sustain future growth. The U.S. Geological Survey, in coopera-tion with Douglas County, began a study to update estimates of water-budget components in Carson Valley for current climatic conditions. Data collected at 19 sites included 9 continuous records of tributary streamflows, 1 continuous record of outflow from the valley, and 408 measurements of 10 perennially flowing but ungaged drainages. These data were compiled and analyzed to provide updated computations and estimates of streamflows tributary to Carson Valley, 1990-2002.

Mean monthly and annual flows were computed from continuous records for the period 1990-2002 for five streams, and for the period available, 1990-97, for four streams. Daily mean flow from ungaged drainages was estimated using multivariate regressions of individual discharge measurements against measured flow at selected continuous gages. From the estimated daily mean flows, monthly and annual mean flows were calculated from 1990 to 2002. These values were used to compute estimates of mean monthly and annual flows for the ungaged perennial drainages. Using the computed and estimated mean annual flows, annual unit-area runoff was computed for the perennial drainages, which ranged from 0.30 to 2.02 feet.

For the period 1990-2002, estimated inflow of perennial streams tributary to Carson Valley totaled about 25,900 acrefeet per year. Inflow computed from gaged perennial drainages totaled 10,300 acre-feet per year, and estimated inflow from ungaged perennial drainages totaled 15,600 acre-feet per year. The annual flow of perennial streams ranges from 4,210 acrefeet at Clear Creek to 450 acre-feet at Stutler Canyon Creek. Differences in unit-area runoff and in the seasonal timing of flow likely are caused by differences in geologic setting, altitude, slope, or aspect of the individual drainages.

The remaining drainages are ephemeral and supply inflow to the valley floor only during spring runoff in wet years or during large precipitation events. Annual unit-area runoff for the perennial drainages was used to estimate inflow from ephemeral drainages totaling 11,700 acre-feet per year.
The totaled estimate of perennial and ephemeral tributary inflows to Carson Valley is 37,600 acre-feet per year. Gaged perennial inflow is 27 percent of the total, ungaged perennial inflow is 42 percent, and ephemeral inflow is 31 percent. The estimate is from 50 to 60 percent greater than three previous estimates, one made for a larger area and similar to two other estimates made for larger areas. The combined uncertainty of the estimates totaled about 33 percent of the total inflow or about 12,000 acre-feet per year.

\section{INTRODUCTION}

Rapid population growth and residential development in Carson Valley is causing concern over the continued availability of water resources to sustain future growth. As growth continues, the effects of changes on ground-water recharge and discharge are uncertain. These effects may change the outflow of the Carson River and, in turn, affect water users dependent on sustained river flow downstream from Carson Valley (fig. 1)

In the early 1980's, the U.S. Geological Survey (USGS) made estimates of water-budget components for Carson Valley (Maurer, 1986). Since that time, much additional hydrologic data have been collected in the valley. The USGS, in cooperation with Douglas County, began a study in February 2003 to update estimates of water-budget components in Carson Valley to reflect current climatic conditions.

Data on streamflows tributary to Carson Valley have been collected by the USGS since the early 1980's, in cooperation with Douglas County and the Carson Water Subconservancy District. Data were collected at 9 continuously recording streamflow gages and at 10 sites in ungaged drainages where periodic measurements were made (fig. 2). The analysis of the data collected provides updated computations and estimates of streamflow tributary to Carson Valley.

\section{Purpose and Scope}

This report presents updated computations and estimates of perennial streamflows tributary to Carson Valley. The computations are derived for drainages having continuously recorded streamflow, and the estimates are derived from 


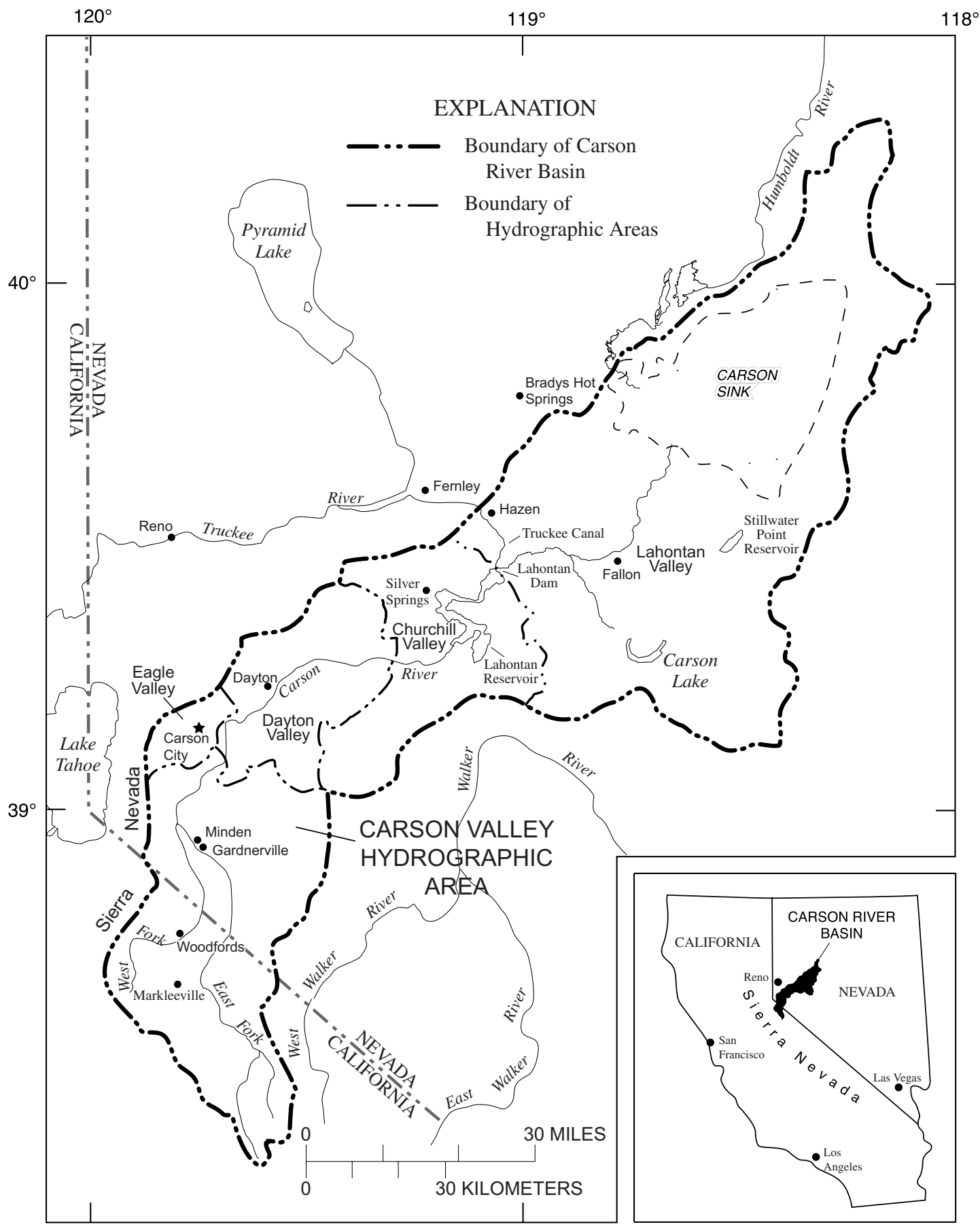

Figure 1. Locations of Carson River Basin and Carson Valley Hydrographic Areas. 


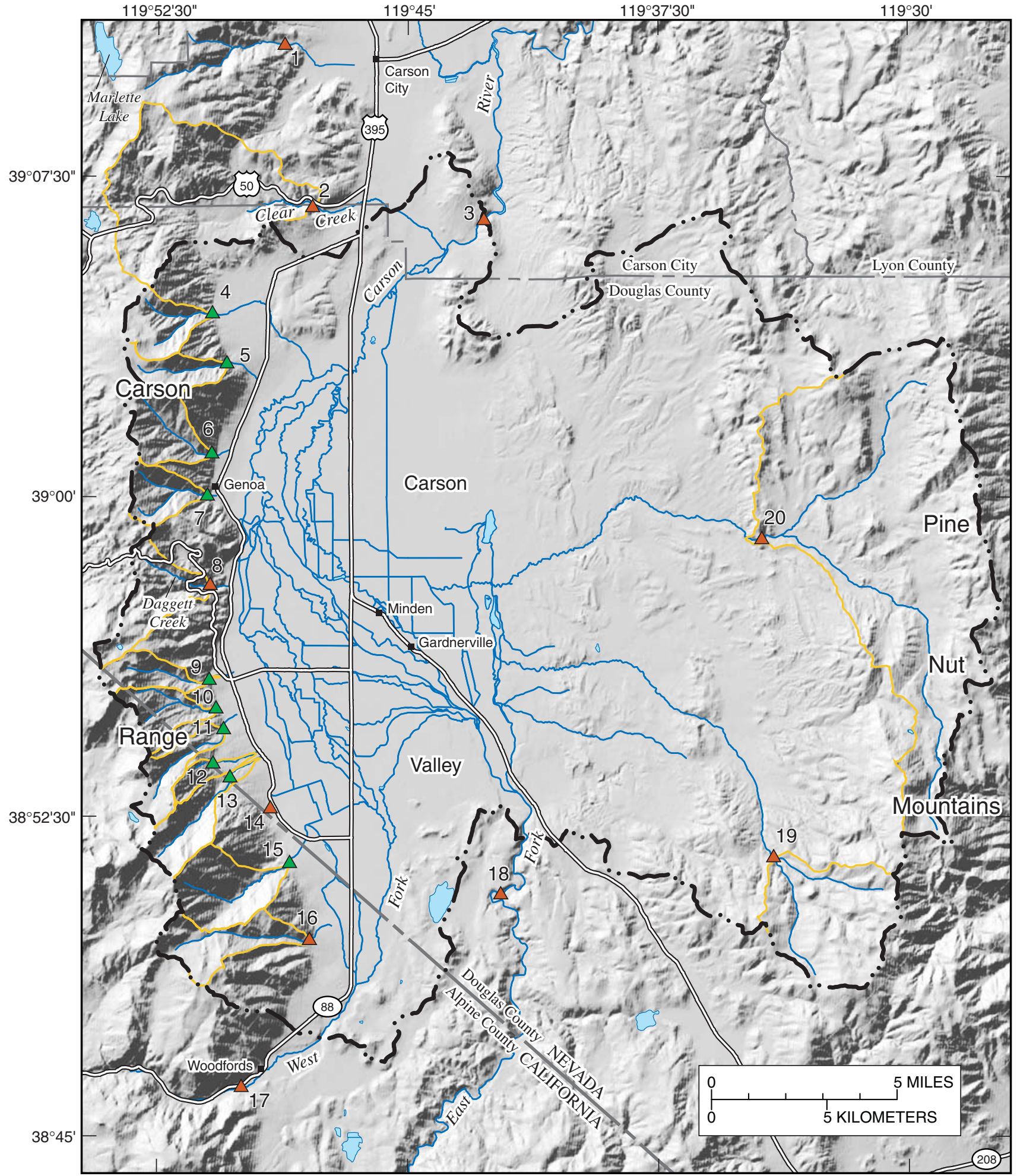

Base from U.S. Geological Survey digital data, 1:100,000, 1979-1988. Universal Transverse Mercator projection, North American Datum of 1927. Shaded-relief base from 30-meter Digital Elevation Model; sun illumination from northwest at 30 degrees above horizon.

\section{EXPLANATION}

Boundary of Carson Valley subarea and study area
Boundary of perennial stream drainage

$\triangle \quad$ Continuous gage site

$\triangle \quad$ Periodic measurement site

Figure 2. Location of surface-water sites used for this study, Carson Valley subarea and study area, and physiographic features of Carson Valley. See table 1 for site names. 
analysis of streamflow data collected at ungaged drainages. The computations and estimates are made for a common period of record 1990-2002.

Mean monthly and annual flows were computed from continuous records for the period 1990-2002 for five streams, and for the period available, 1990-97, for four streams. Multivariate regression equations were developed to estimate daily mean streamflows at the 10 perennial but ungaged drainages using the flow at selected gaged sites. The estimated daily mean flows for each of the 10 ungaged drainages from 1990 to 2002 were used to calculate monthly and annual mean flows for each month and year, and mean monthly and annual flow for the period 1990-2002. Mean annual flows computed for the gaged drainages are compared to long-term values. Unitarea runoff values are calculated for the perennial streams and used to estimate tributary inflows from ephemeral drainages. Total tributary inflow is compared to previous estimates, and uncertainties in the estimates are discussed.

\section{Acknowledgments}

The authors thank John Ascuaga and the Sierra Nevada Golf Ranch for providing access to private property for streamflow measurements.

\section{Geographic Setting of Carson Valley}

Carson Valley is in Douglas County, NV, about 4 mi south of Carson City, Nevada's capital (fig. 1). The southern end of the valley extends about $3 \mathrm{mi}$ into Alpine County, CA. The floor of the valley is oval-shaped, about $20 \mathrm{mi}$ long and $8 \mathrm{mi}$ wide, and slopes from about 5,000 ft above sea level at the southern end to about $4,600 \mathrm{ft}$ at the northern end. On the western side of the valley floor, the Carson Range rises abruptly with mountain peaks ranging from 9,000 to $11,000 \mathrm{ft}$. On the eastern side of the valley, the Pine Nut Mountains rise more gradually to peaks ranging from 8,000 to $9,000 \mathrm{ft}$.

The valley floor is covered with native pasture grasses, crop lands of alfalfa with some garlic and onion, and near the northern end, phreatophytes such as greasewood, rabbitbrush, and big sage. In 2002, about 31,000 acres of land in Douglas County were irrigated of which 16,000 acres were harvested cropland and 15,000 acres were pasture lands (U.S. Department of Agriculture, 2004). On the western side of the valley, bitterbrush and sagebrush cover steep alluvial fans, and manzanita and ponderosa pine cover the slopes of the Carson
Range. On the eastern side of the valley, sagebrush and rabbitbrush cover the alluvial fans and foothills of the Pine Nut Mountains and piñon and juniper are found on the slopes.

The major incorporated towns in the valley are Minden and Gardnerville (fig. 1) with populations of 2,800 and 3,400, respectively, in 2000 (U.S. Census Bureau, 2003). Subdivisions on the southern and northern ends of the valley are growing rapidly, with populations totaling greater than 20,000 in 2000 (U.S. Census Bureau, 2003). In addition, development is active along the eastern and western sides of the valley, and on the valley floor on land that historically has been agricultural. Douglas County as a whole has grown from a population of about 28,000 in 1990 to 41,000 in 2000, an increase of about 49 percent (Economic Research Service, 2004).

The major hydrographic feature of the valley is the Carson River. The East and West Forks of the Carson River enter the valley from the southeast and southwest corners, respectively, and flow northward to join near Genoa. The mainstem of the Carson River continues north and leaves the valley southeast of Carson City. Flow of the Carson River is diverted across the valley floor through a network of canals and ditches for flood irrigation of crops.

\section{Hydrologic Setting of Carson Valley}

For purposes of this study, the boundary of Carson Valley was delineated as a subarea of the entire Carson Valley Hydrographic Area ${ }^{1}$ (fig. 3). The subarea boundary was selected to include only those parts of the hydrographic area connected by permeable aquifer materials capable of transmitting ground water to aquifers beneath Carson Valley. The greatest difference between the subarea and overall hydrographic area is along the southern study-area boundary, where the headwaters of the West and East Forks Carson River have been excluded. The Carson Valley subarea is 253,570 acres or about $396 \mathrm{mi}^{2}$ (fig. 3) out of a total drainage of $876 \mathrm{mi}^{2}$.

The hydrology of Carson Valley is dominated by flow of the Carson River. Mean annual inflow from the East and West Forks, respectively, is 276,400 acre-ft (period of record 1890 2002; fig. 1) and 80,320 acre-ft (period of record 1901-2002; Berris and others, 2003, p. 178 and 185) for a total of 356,720 acre-ft. Mean annual outflow of the mainstem Carson River is 296,500 acre-ft (period of record 1940-2002; Berris and others, 2003, p. 191). Numerous perennial streams drain the Carson Range, whereas only two perennial streams, Buckeye and Pine Nut Creeks (fig. 2), drain the Pine Nut Mountains.

Infiltration of surface water through the beds of streams and ditches, and beneath flood-irrigated fields maintains a shallow water table below much of the valley floor where depth

\footnotetext{
${ }^{1}$ The U.S. Geological Survey and Nevada Division of Water Resources delineated formal hydrographic areas in Nevada systematically in the late 1960's for scientific and administrative purposes (Cardinalli and other, 1968; Rush, 1968). The official hydrographic-area names, numbers, and geographic boundaries continue to be used in Geological Survey scientific reports and Division of Water Resources administrative activities. Hydrographic-area boundaries generally coincide with drainage-area boundaries.
} 
INTRODUCTION 5
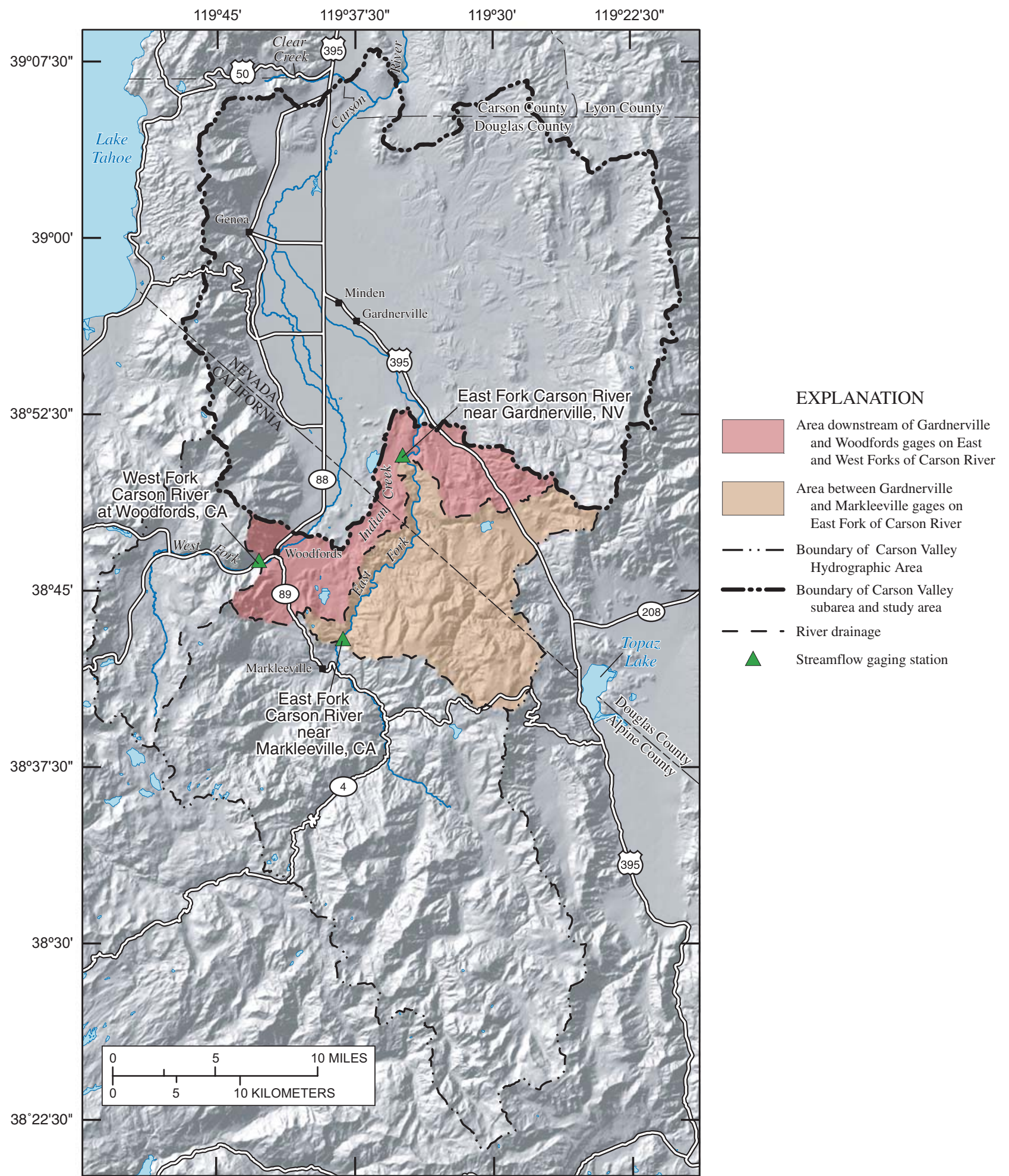

Base from U.S. Geological Survey digital data, 1:100,000, 1979-1988. Universal Transverse Mercator projection, North American Datum of 1927. Shaded-relief base from 30-meter Digital

Elevation Model; sun illumination from northwest at 30 degrees above horizon.

Figure 3. Location of surface-water sites used for delineation of boundaries in previous studies, Carson Valley subarea and study area, and physiographic features of Carson Valley. 
to ground water is less than $5 \mathrm{ft}$ (Maurer and Peltz, 1994, sheet 2). Depth to water beneath alluvial fans on the western side of the valley increases to greater than $200 \mathrm{ft}$ within $1 \mathrm{mi}$ of the valley floor; whereas, depth to water on the eastern side of the valley increases more slowly, reaching $200 \mathrm{ft}$ about $3 \mathrm{mi}$ from the valley floor (Maurer and Peltz, 1994, sheet 2). Beneath the valley floor, ground water flows at a low gradient towards the Carson River from the east and west, and then flows northward.

Carson Valley lies in the rain shadow of the Sierra Nevada. In the valley, annual precipitation at Minden averages $8.4 \mathrm{in} / \mathrm{yr}$ (period of record 1971-2000; National Oceanic and Atmospheric Administration, 2002, p. 12). In contrast, the top of the Carson Range receives 25.5 in/yr (period of record 1971-2000, Western Regional Climate Center, 2003). Near the top of the Pine Nut Mountains precipitation averages $15.7 \mathrm{in} / \mathrm{yr}$ (period of record 1984-2002; Dan Greenlee, Natural Resources Conservation Service, written commun., 2003).

\section{Previous Investigations}

The first estimate of streamflows tributary to Carson Valley was made by Piper (1969). Piper used gaged streamflow at 15 sites in and near Carson Valley to derive a relation between runoff and altitude, and a map showing the distribution of a term called "coefficients of horizontal variability" of runoff over gaged and ungaged drainages. From these coefficients he estimated about 24,800 acre-ft/yr of long-term mean runoff from drainages tributary to Carson Valley, including the Clear and Indian Creeks drainages (fig. 3; Piper, 1969, p. 7).

The Nevada State Engineer (1971, p. 57) estimated 24,000 acre-ft of annual runoff from the mountain blocks to the valley floor. No details are provided about the method used to estimate runoff or if the estimate includes perennial and ephemeral flows (Nevada State Engineer, 1971, p. 51-52). The area included in the estimate likely is similar to that of the present study.

Glancy and Katzer (1976) estimated streamflows tributary to Carson Valley using an indirect method developed by Moore (1968). Moore's method uses a relation between altitude and runoff that varies for different regions within Nevada and does not distinguish between perennial and ephemeral streamflows. The estimates of runoff were refined using measurements of channel geometry as described by Moore (1968, p. 36-38), and checked for accuracy using miscellaneous streamflow measurements (Glancy and Katzer, 1976, p. 32). The resulting estimate of average streamflows tributary to Carson Valley was 15,000 acre-ft/yr for the Nevada portion of the valley, and 34,000 acre$\mathrm{ft} / \mathrm{yr}$ for the combined Nevada and California segments of the valley downstream from Woodfords on the West Fork Carson River and Markleeville on the East Fork Carson River (fig. 3; Glancy and Katzer, 1976, p. 34).

Spane (1977) estimated annual runoff within the Carson Valley Basin using methods similar to those of Glancy and Katzer (1976), including perennial and ephemeral streamflows. Spane derived estimates of about 27,400 acre-ft/yr for the Carson Range including the Clear Creek drainage, 15,400 acre- $\mathrm{ft} / \mathrm{yr}$ for the Pine Nut Mountains, and 1,900 acre-ft/yr for the Indian Creek drainage for a total of about 45,000 acre-ft/yr (Spane, 1977, p. 65 and 66).

Streamflow tributary to Carson Valley was estimated by Maurer (1986) who made periodic measurements from 1981 through 1983 at eight perennial streams draining the Carson Range which included Sierra Canyon, Genoa Canyon, Mott Canyon, Monument, Stutler Canyon, Jobs Canyon, Luther, and Fredericksburg Creeks (fig. 2, table 1). These measurements were used to develop correlations between flow at each sites and the recorded flow at the USGS gaging station at Daggett Creek near Genoa, NV (site 8; fig. 2). The correlations were then used to estimate mean annual streamflow for the eight streams. The resulting estimate of streamflow from the eight perennial streams including Daggett Creek was 18,400 acre-ft/yr (Maurer, 1986, p. 15). To estimate streamflow from ephemeral drainages surrounding Carson Valley, Maurer (1986, p. 37) subtracted the estimate of 18,400 acre-ft/yr for perennial flow from the estimate of 24,000 acre-ft/yr for the total runoff to Carson Valley by the Nevada State Engineer (1971, p. 57) to obtain an estimate of total ephemeral streamflow of about 6,000 acre-ft/yr. Maurer (1986, p. 16) estimated the mean annual flow of principal springs in Carson Valley including Benson, Miller, Barber, Sheridan, and Walley's Hot Springs to total 5,200 acre-ft/yr.

Hess (1999, p. 4 and 9) used the recorded flow at 3 USGS gaging stations along with annual precipitation at 3 stations to develop regression equations for flow from 10 perennial streams tributary to Carson Valley. The 10 streams included Clear, Sierra Canyon, Genoa Canyon, Daggett, Mott Canyon, Monument, Sheridan, Jobs Canyon, Luther, and Fredericksburg Creeks. Equations were used to compute daily streamflow for input to a surface-water routing model of the Carson River for the period 1978-97 (Hess, 1999, p. 9). However, long-term average values of tributary streamflows from the 10 streams were not reported.

\section{METHODS USED}

Updated computations and estimates of streamflows tributary to Carson Valley were derived for 18 sites and for Carson River outflow from the valley. Streamflow data were collected continuously at 8 tributaries and Carson River outflow, and periodically at 10 sites in ungaged drainages (fig. 2 , table 1). The data from the gaged streams and the periodic measurements have been previously published in the annual series "Water Resources Data for Nevada." The computations and estimates are made for a common and recent period of record 1990-2002.

The tributaries include: Clear, Water Canyon, James Canyon, Sierra Canyon, Genoa Canyon, Daggett, Mott Canyon, Monument, Stutler Canyon, Sheridan, Jobs Canyon, Luther, and Fredericksburg Creeks; Miller Spring; East and West Forks Carson River draining the Carson Range; and Buckeye and Pine 
Table 1. Site identifier information, period of record, and drainage area for surface-water sites in Carson Valley

[Abbreviations: C, continuous gage site; $\mathrm{P}$, periodic measurement]

\begin{tabular}{|c|c|c|c|c|c|c|c|}
\hline \multirow{2}{*}{$\begin{array}{c}\text { Site no. } \\
\text { (see } \\
\text { fig. 2) }\end{array}$} & \multirow{2}{*}{ Site type } & \multirow{2}{*}{ Site identifier } & \multirow{2}{*}{ Site name } & Latitude & Longitude & \multirow{2}{*}{ Period of record } & \multirow{2}{*}{$\begin{array}{l}\text { Drainage area, } \\
\text { in square miles }\end{array}$} \\
\hline & & & & \multicolumn{2}{|c|}{ in degrees, minutes, seconds } & & \\
\hline $1^{1}$ & $\mathrm{C}$ & 10311200 & Ash Canyon Creek near Carson City, NV & $39^{\circ} 10^{\prime} 35^{\prime \prime}$ & $119^{\circ} 48^{\prime} 17^{\prime \prime}$ & 1976-2002 & 5.2 \\
\hline 2 & $\mathrm{C}$ & 10310500 & Clear Creek near Carson City, NV & $39^{\circ} 06^{\prime} 48^{\prime \prime}$ & $119^{\circ} 47^{\prime} 50^{\prime \prime}$ & $\begin{array}{l}1963-1981 \\
1989-2002\end{array}$ & 15.5 \\
\hline 3 & $\mathrm{C}$ & 10311000 & Carson River near Carson City, NV & $39^{\circ} 06^{\prime} 28^{\prime \prime}$ & $119^{\circ} 42^{\prime} 44^{\prime \prime}$ & 1939-2002 & 886 \\
\hline 4 & $\mathrm{P}$ & 10310430 & Water Canyon Creek near Genoa, NV & $39^{\circ} 04^{\prime} 17^{\prime \prime}$ & $119^{\circ} 50^{\prime} 52^{\prime \prime}$ & $1996-2002$ & 2.69 \\
\hline 5 & $\mathrm{P}$ & 10310425 & James Canyon Creek near Genoa, NV & $39^{\circ} 03^{\prime} 07^{\prime \prime}$ & $119^{\circ} 50^{\prime} 25^{\prime \prime}$ & $1997-2002$ & 2.07 \\
\hline 6 & $\mathrm{P}$ & 10310415 & Sierra Canyon Creek near Genoa, NV & $39^{\circ} 01^{\prime} 01^{\prime \prime}$ & $119^{\circ} 50^{\prime} 52^{\prime \prime}$ & $\begin{array}{l}1981-1983 \\
1988-1996\end{array}$ & 3.19 \\
\hline 7 & $\mathrm{P}$ & 10310410 & Genoa Canyon Creek at Genoa, NV & $39^{\circ} 00^{\prime} 02^{\prime \prime}$ & $119^{\circ} 51^{\prime} 00^{\prime \prime}$ & $\begin{array}{l}1981-1982 \\
1988-2000\end{array}$ & 2.24 \\
\hline 8 & $\mathrm{C}$ & 10310400 & Daggett Creek near Genoa, NV & $38^{\circ} 57^{\prime} 55^{\prime \prime}$ & $119^{\circ} 50^{\prime} 55^{\prime \prime}$ & $\begin{array}{l}1965-1983 \\
1988-2002\end{array}$ & 3.82 \\
\hline 9 & $\mathrm{P}$ & 10310385 & Mott Canyon Creek near Minden, NV & $38^{\circ} 55^{\prime} 44^{\prime \prime}$ & $119^{\circ} 50^{\prime} 57^{\prime \prime}$ & $\begin{array}{l}1981-1983 \\
1987-1996\end{array}$ & 2.02 \\
\hline 10 & $\mathrm{P}$ & 10310380 & Monument Creek near Minden, NV & $38^{\circ} 55^{\prime} 03^{\prime \prime}$ & $119^{\circ} 50^{\prime} 44^{\prime \prime}$ & 1997-2002 & 2.37 \\
\hline 11 & $\mathrm{P}$ & 10310375 & Stutler Canyon Creek near Minden, NV & $38^{\circ} 54^{\prime} 35^{\prime \prime}$ & $119^{\circ} 50^{\prime} 32^{\prime \prime}$ & $1997-2002$ & 2.34 \\
\hline 12 & $\mathrm{P}$ & 10310370 & Sheridan Creek near Minden, NV & $38^{\circ} 53^{\prime} 46^{\prime \prime}$ & $119^{\circ} 50^{\prime} 49^{\prime \prime}$ & $\begin{array}{l}1981-1983 \\
1989-1996\end{array}$ & 1.01 \\
\hline 13 & $\mathrm{P}$ & 10310360 & Jobs Canyon Creek near Minden, NV & $38^{\circ} 53^{\prime} 26^{\prime \prime}$ & $119^{\circ} 50^{\prime} 20^{\prime \prime}$ & $\begin{array}{l}1981-1983 \\
1989-2002\end{array}$ & 2.97 \\
\hline 14 & $\mathrm{C}$ & 10310350 & Miller Spring near Sheridan, NV & $38^{\circ} 52^{\prime} 43^{\prime \prime}$ & $119^{\circ} 49^{\prime} 07^{\prime \prime}$ & $1989-1997$ & indeterminate \\
\hline 15 & $\mathrm{P}$ & 10310330 & Luther Creek near Fredericksburg, CA & $38^{\circ} 51^{\prime} 26^{\prime \prime}$ & $119^{\circ} 48^{\prime} 32^{\prime \prime}$ & $\begin{array}{l}1981-1983 \\
1989-1996\end{array}$ & 4.42 \\
\hline 16 & $\mathrm{C}$ & 10310300 & $\begin{array}{l}\text { Fredericksburg Canyon Creek near } \\
\text { Fredericksburg, CA }\end{array}$ & $38^{\circ} 49^{\prime} 38^{\prime \prime}$ & $119^{\circ} 47^{\prime} 56^{\prime \prime}$ & 1989-2000 & 3.71 \\
\hline 17 & $\mathrm{C}$ & 10310000 & West Fork Carson River at Woodfords, CA & $38^{\circ} 46^{\prime} 11^{\prime \prime}$ & $119^{\circ} 49^{\prime} 58^{\prime \prime}$ & $1938-2002$ & 65.4 \\
\hline 18 & $\mathrm{C}$ & 10309000 & East Fork Carson River near Gardnerville, NV & $38^{\circ} 50^{\prime} 42^{\prime \prime}$ & $119^{\circ} 42^{\prime} 13^{\prime \prime}$ & $1939-2002$ & 356 \\
\hline 19 & $\mathrm{C}$ & 10309050 & Pine Nut Creek near Gardnerville, NV & $38^{\circ} 51^{\prime} 34^{\prime \prime}$ & $119^{\circ} 34^{\prime} 02^{\prime \prime}$ & $1980-1997$ & 9.99 \\
\hline 20 & $\mathrm{C}$ & 10309070 & Buckeye Creek near Minden, NV & $38^{\circ} 58^{\prime} 59^{\prime \prime}$ & $119^{\circ} 34^{\prime} 23^{\prime \prime}$ & 1980-1997 & 45.6 \\
\hline
\end{tabular}

${ }^{1}$ In Eagle Valley Hydrographic Area. 


\section{Updated Computations and Estimates of Streamflows Tributary to Carson Valley, Douglas County, NV, and Alpine County, CA, 1990-2002}

Nut Creeks draining the Pine Nut Mountains (table 1). Records of the Nevada State Engineer (1914) indicate that the drainage labeled Jobs Canyon on the Minden 1:24,000-scale USGS topographic map was previously called Barber Canyon. To reduce confusion and maintain consistency with published USGS topographic maps, canyon and creek names from USGS topographic maps will be used in this report. Measurements of Sheridan Creek include flow from a drainage labeled Barber Creek on 1:24,000-scale USGS topographic maps. Measurements of Stutler Creek do not include small diversions upstream of the measuring point. The Clear Creek drainage is north of the Carson Valley hydrographic area and the Carson Valley subarea and study area for this report, but is tributary to the northern part of Carson Valley, entering the Carson River about $1.5 \mathrm{mi}$ upstream from the point where the river leaves the hydrographic area.

With the exceptions of Mott Canyon, Sheridan, and Jobs Canyon Creeks, all data-collection sites draining the Carson Range are upstream of the contact between bedrock forming the mountain block and unconsolidated sediments forming alluvial fans at the mouths of the creeks. The site at Mott Canyon Creek is about 2,000 ft downstream from the bedrock contact; whereas, the sites at Sheridan and Jobs Canyon Creeks are about $1 \mathrm{mi}$ downstream. Estimates of tributary inflow at these sites do not account for streamflow that may be lost to infiltration between the bedrock contact and the point of measurement. The sites at Buckeye and Pine Nut Creeks are near the bedrock contact of the Pine Nut Mountains and near the downstream point where streamflow consistently is perennial.

Mean monthly and annual flows were computed from continuous records for the period 1990-2002 for five streams (sites 2, 3, 8, 17, and 18; fig. 2, table 1), and for the period available, 1990-97, for four streams (sites 14, 16, 19 and 20).

The daily mean flows recorded at 5 gaged drainages in the Carson Range were used to derive estimates of streamflow tributary to Carson Valley from the 10 ungaged drainages where 408 measurements have been made. The gaged drainages selected were Ash Canyon, Clear, and Daggett Creeks, and the West and East Forks Carson River (sites 1, 2, 8, 17, and 18). These drainages were selected to obtain the longest common and recent period of record from gaged drainages on the east side of the Carson Range in or near Carson Valley that coincides with the period when flow measurements were made at the ungaged drainages, 1990-2002.

The use of gaged streamflow data and individual flow measurements to derive estimates of mean monthly and annual flow for ungaged drainages is presented by Riggs (1969). Riggs compared individual flow measurements made at the same time each month on ungaged streams with the daily mean flow on the same day of a nearby gaged stream with continuous flow record. By using this method it is assumed that the discharge measured at the middle of the month has about the same ratio to the daily mean discharge on the gaged stream as the ratio of the two streams' monthly means. Using a different relation for each month, estimates of monthly mean, annual mean, and long-term mean annual flow may be made for the ungaged drainages.
Periodic measurements were made on about a quarterly basis at the 10 ungaged drainages in Carson Valley (table 1), but the monthly data indicated by Riggs (1969) are not available. For this reason an alternative approach was derived.

The method used for this study follows Riggs' (1969) general concept of comparing individual discharge measurements of ungaged streams against daily mean discharge for the same day on gaged streams. Similar to the method of Riggs, it is assumed that the individual measurements adequately represented daily mean flow for the ungaged drainages, and most measurements were made when flow was stable. Multivariate regression models were created for each ungaged drainage. All five of the continuous record sites were considered in each model, rather than choosing one particular drainage for each model. Instead of estimating monthly mean flows, the models were used to compute daily mean flows for the period 1990 2002.

Standard statistical methods and software were used to develop regression equations (SAS Institute, Inc., 1989). Individual measurements of flow at each of the ungaged drainages were the dependent variables, and the concurrent daily mean flow at the gaged drainages were the independent variables. Although flows are estimated for the ungaged drainages for the period 1990-2002, discharge measurements from as early as 1969 were used in developing the regression models. The number of discharge measurements available for individual drainages ranged from 24 to 65 (table 2).

Logarithmic models were used for the analysis, with the dependent and independent variable transformed by taking the common (base 10) logarithm. Stepwise forward and backward regression procedures were used to identify the stream gages that best predicted streamflow at the ungaged sites and derive the final models (routine PROC REG; SAS Institute, Inc., 1999).

Stepwise forward regression enters the most significant variable not currently included in the model at each step, provided that the significance is at or below a minimum required significance, as determined by an F-test. The threshold significance for entry was 0.15 . All variables in the model at that step are then examined and any with a significance that falls above a threshold value of 0.05 are eliminated. Backward regression enters all the variables at the first step and eliminates the least significant above a threshold value of 0.10 at each step, until all remaining variables are significant at or below a threshold value of 0.05 . This process includes all variables in the final models that are significant at the 95 percent confidence level, and determines the significance of combinations of the independent variables.

Examination of plots of simulated daily mean flows and measured flows led to adding a variable of observed flows that had been lagged by 1 day for some drainages. For example, the lagged flow of Ash Canyon Creek on January 3, 1995, would be the daily mean flow from January 2, 1995. Lagging by 1 day attempts to adjust for the difference in timing of hydrologic response in the compared drainages to precipitation events. The base 10 logarithms for lagged flows were added to the models 
METHODS USED 9

Table 2. Regression model equations, $\mathrm{R}^{2}$ values, percent error, and number of measurements for ungaged drainages in Carson Valley with periodic measurements

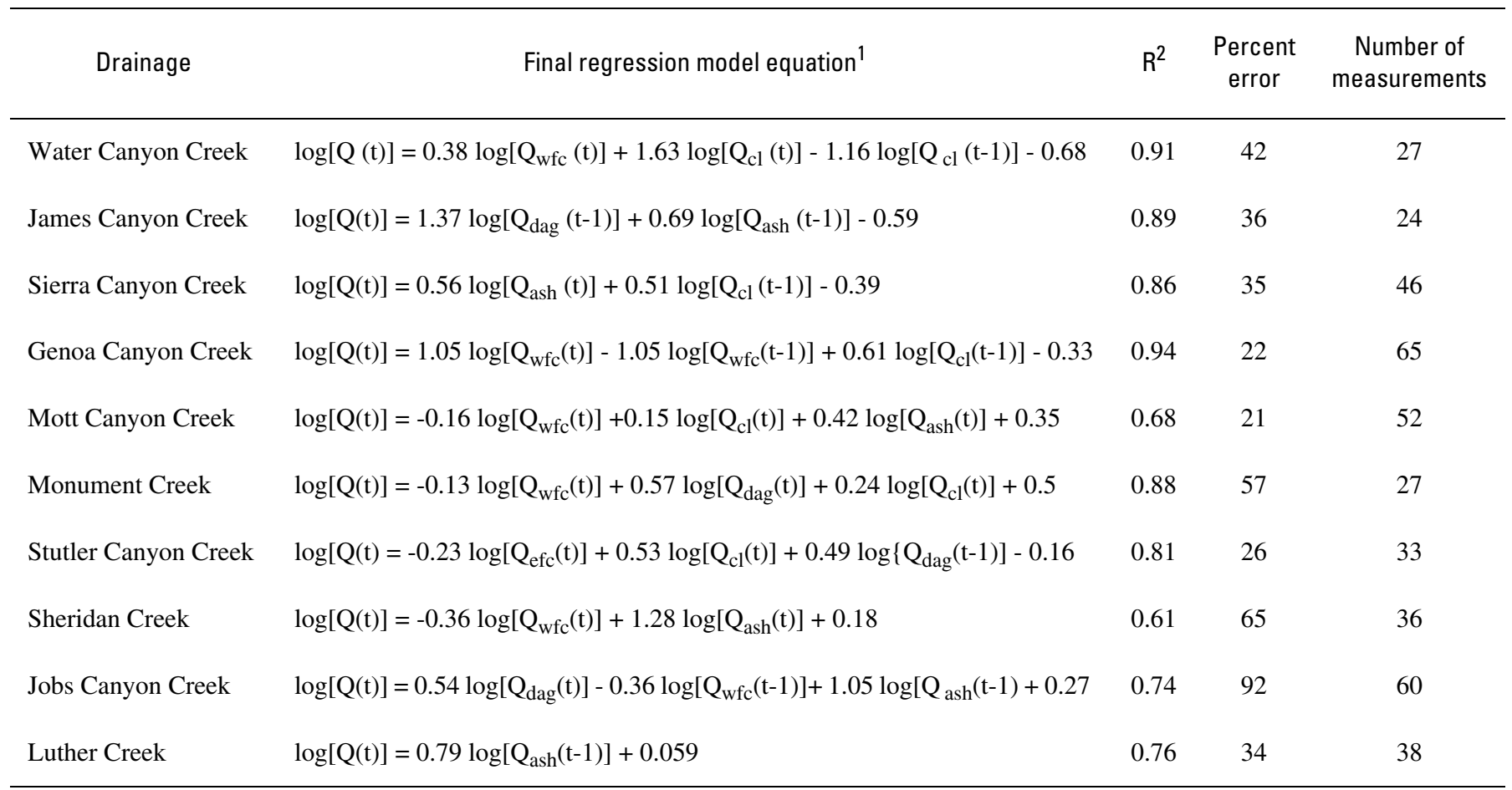

${ }^{1} \mathrm{Q}(\mathrm{t})$ is daily flow, $\mathrm{Q}(\mathrm{t}-1)$ is daily flow lagged by 1 day, $\mathrm{Q}_{\mathrm{wfc}}$ is daily flow at West Fork Carson River, $\mathrm{Q}_{\mathrm{efc}}$ is daily flow at East Fork Carson River, $\mathrm{Q}_{\mathrm{cl}}$ is daily flow at Clear Creek, $Q_{\text {dag }}$ is daily flow at Daggett Creek, $Q_{a s h}$ is daily flow Ash Canyon Creek.

and the models were rerun using lagged values, again using stepwise forward and backward regression. In some cases, model improvements were great enough to warrant the addition of the lagged variables (table 2).

When the stepwise forward and backward regression procedures resulted in different models for either the lagged or unlagged data, the model with the coefficients of higher significance was chosen. The assumption in this approach is that, in a statistical manner, the gaged basins having characteristics of the greatest similarity to those of the ungaged drainages are selected. The flow data from the gaged streams directly define the coefficients of the models, reflecting a combination of applicable basin characteristics and the hydrologic conditions of the period to be estimated.

The final regression equations listed in table 2 have significant independent variables ranging from 1 to 4 in number and coefficients of determination $\left(\mathrm{R}^{2}\right)$ ranging from 0.61 to $0.94,6$ of 10 which are greater than 0.8 . For comparison, two plots of measured versus simulated flow are shown in figure 4; one showing results for site 4 , Water Canyon Creek (fig. 4A; $\mathrm{R}^{2}=0.91$ ), and one showing results from site 12 , Sheridan Creek (fig. $4 B, \mathrm{R}^{2}=0.61$ ). Because the $\mathrm{R}^{2}$ values may be strongly influenced by outliers such as the high-flow measurements included in some of the data sets (Helsel and Hirsch, 1992, p. 247), the percent errors associated with the final regression models are included in table 2 . The percent error is the standard error expressed as a percent of the mean or the standard error divided by the mean of the measured flows and multiplied by 100 (Tasker, 1978). The percent errors range from 21 percent at Mott Canyon Creek to 92 percent at Jobs Canyon Creek (table 2).

The final model for each ungaged drainage was used to develop a data set of daily mean flows for the period 1990 2002. The simulated flows were plotted for visual comparison of fit and inspected for event timing and overall similarity to gaged values at nearby streams. The final hydrographs for the ungaged drainages showing estimated daily mean flow and periodic discharge measurements from 1990 to 2002 are shown in figure 5 .

The simulated daily mean flow values for each ungaged drainage were used to compute mean flow estimates for each month and year from 1990 to 2002. These values were then used to compute mean monthly (appendix) and annual flow estimates (fig. 6) for the same period in units of acre-feet. The computed and estimated mean annual flow of the perennial streams was used to determine the unit-area runoff, in units of 
A Water Canyon Creek (site 4)

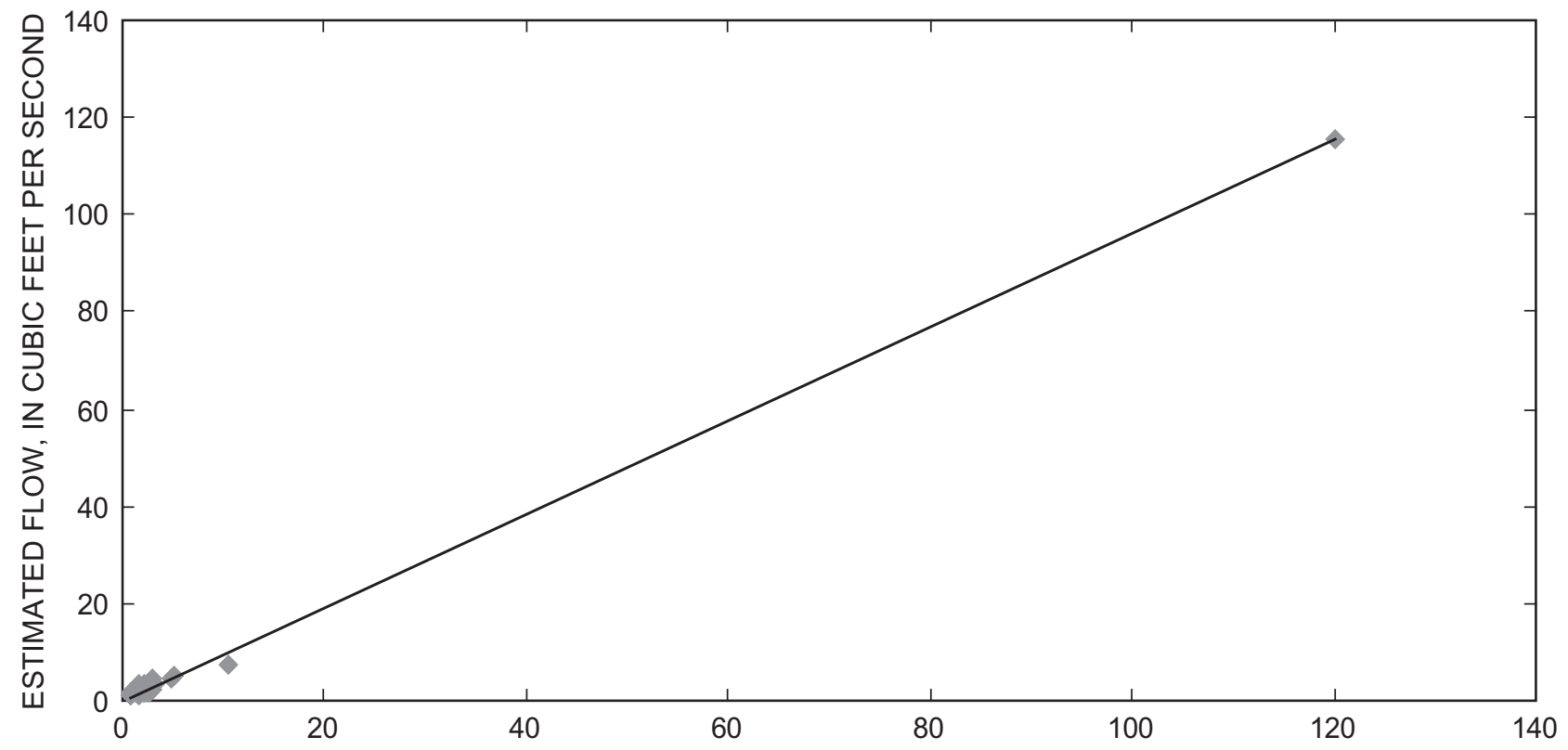

B Sheridan Creek (site 12)

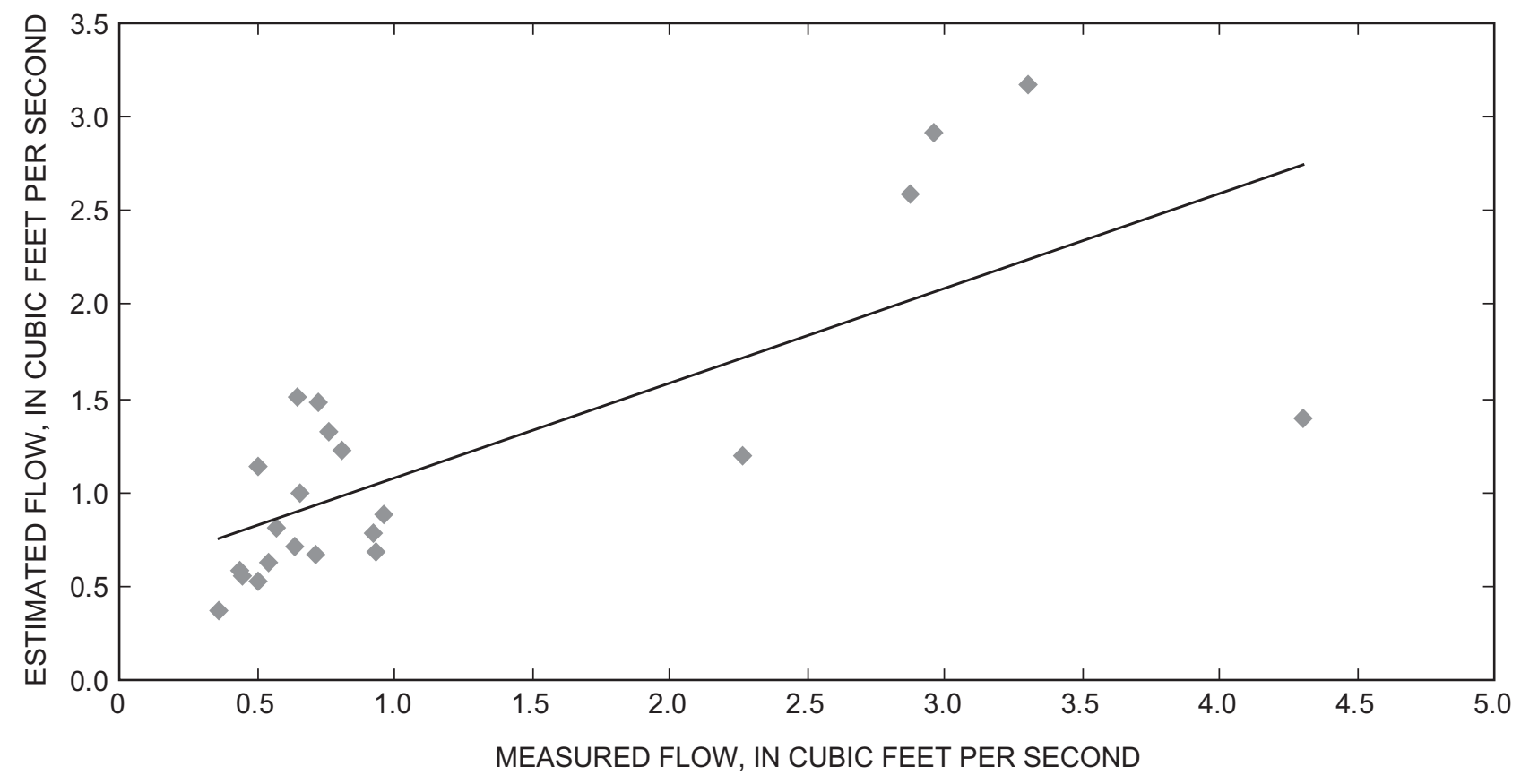

Figure 4. Measured and simulated flows for $(A)$ Water Canyon Creek and $(B)$ Sheridan Creek. 

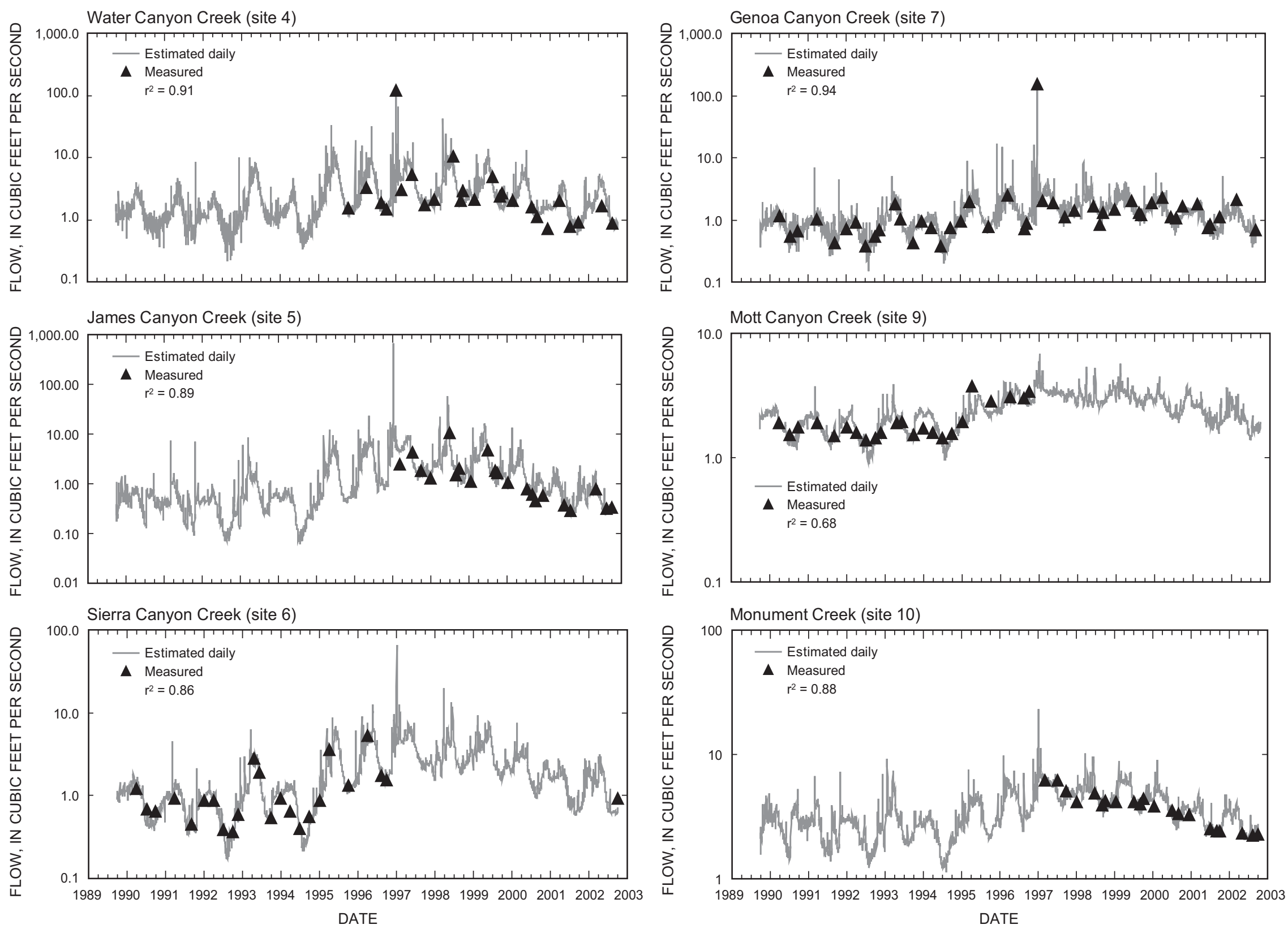

Figure 5. Estimated daily mean flow and periodic measurements of flow for ungaged perennial drainages, 1990-2002. See figure 2 for site locations. 
Stutler Canyon Creek (site 11)

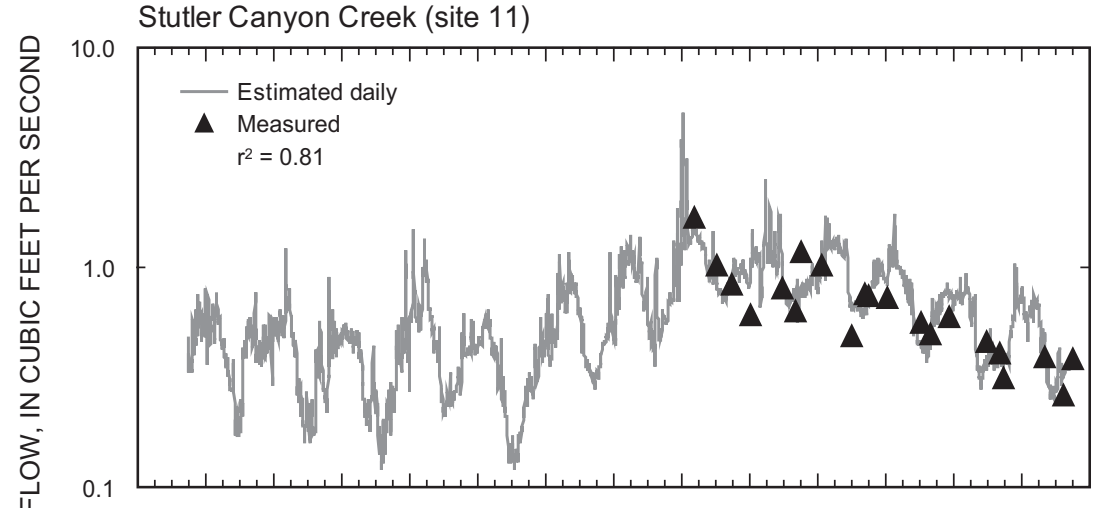

Sheridan Creek (site 12)

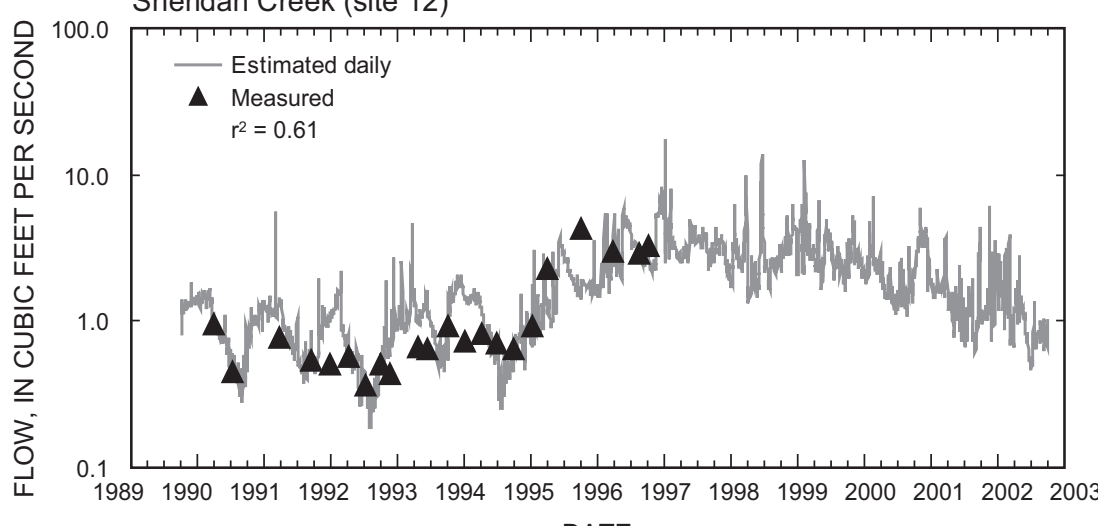
DATE
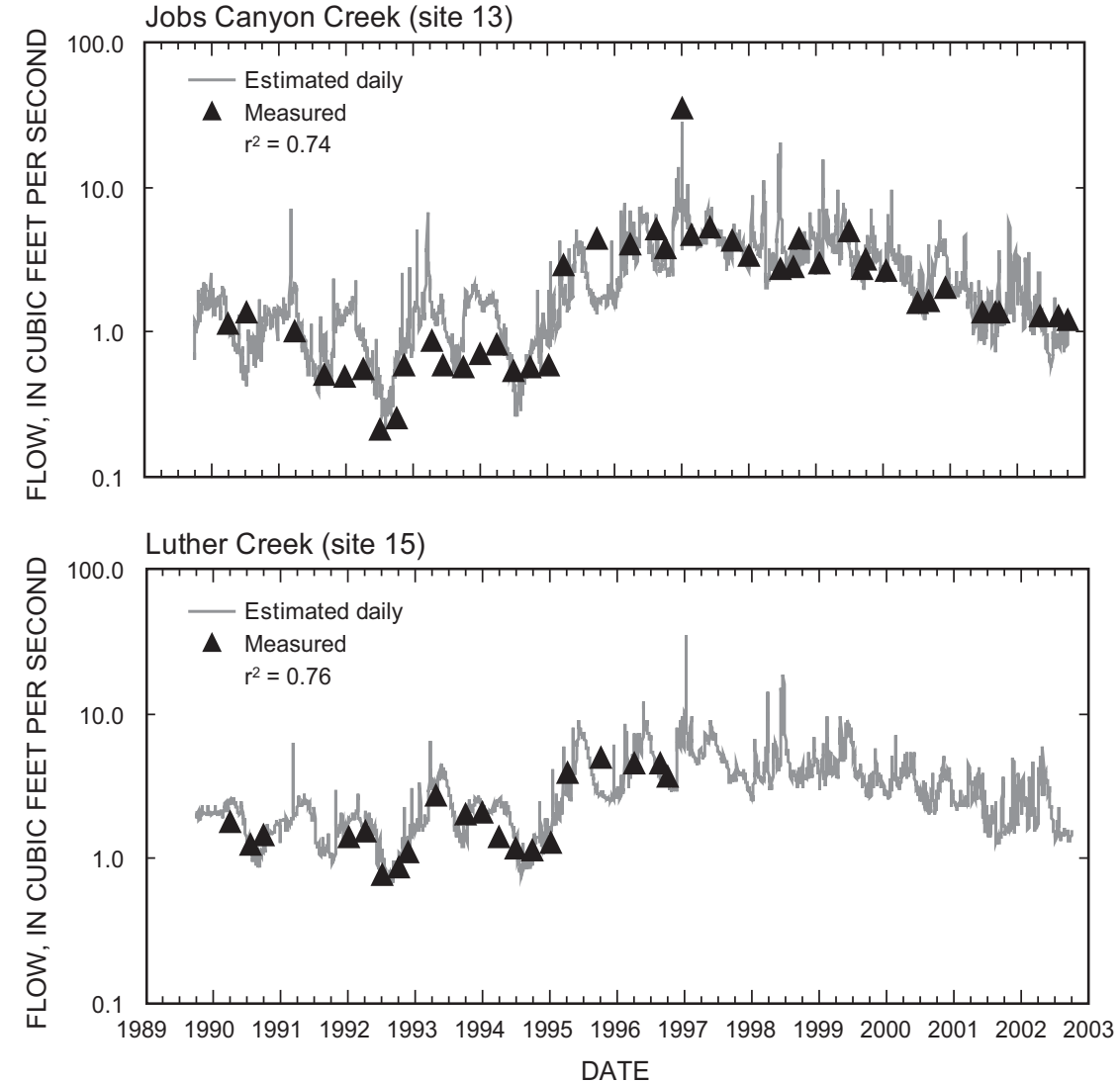

Figure 5. Estimated daily mean flow and periodic measurements of flow for ungaged perennial drainages, 1990-2002—Continued. 


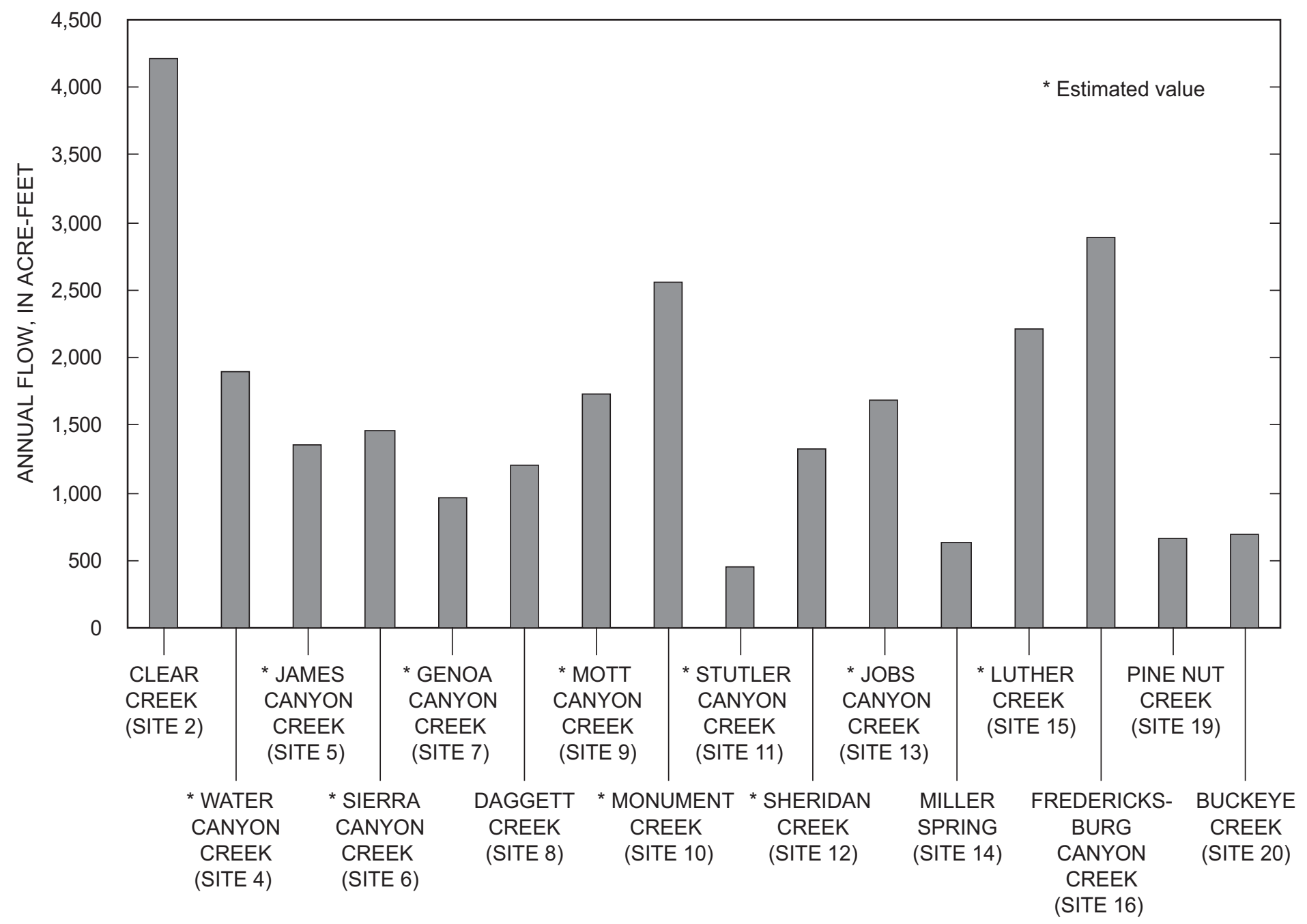

Figure 6. Computed and estimated mean annual flow for gaged and ungaged perennial streams tributary to Carson Valley, 1990-2002. See figure 2 for site location. 
Table 3. Computed and estimated mean annual flow of gaged and ungaged perennial streams and ephemeral drainages tributary to Carson Valley, 1990-2002, mean annual flow for period of record at gaged sites, annual flow estimated by Maurer (1986), drainage area, and unit-area flow

[Abbreviation: na, not applicable]

\begin{tabular}{|c|c|c|c|c|c|c|}
\hline $\begin{array}{l}\text { Site no. } \\
\text { (see fig. 2) }\end{array}$ & Site name & $\begin{array}{l}\text { Computed and estimated } \\
\text { annual flow } 1990-2002^{1} \\
\text { in acre-feet }\end{array}$ & $\begin{array}{l}\text { Annual flow for } \\
\text { period of record, } \\
\text { in acre-feet }\end{array}$ & $\begin{array}{c}\text { Annual flow } \\
\text { estimated by } \\
\text { Maurer (1986), } \\
\text { in acre-feet }\end{array}$ & $\begin{array}{l}\text { Drainage area, } \\
\text { in acres }\end{array}$ & $\begin{array}{l}\text { Annual } \\
\text { unit-area flow }{ }^{2}, \\
\text { in feet }\end{array}$ \\
\hline \multicolumn{7}{|c|}{ Perennial streams } \\
\hline 2 & Clear Creek & 4,210 & 4,070 & na & 9,920 & 0.42 \\
\hline 4 & Water Canyon Creek ${ }^{3}$ & 1,900 & na & na & 1,720 & 1.10 \\
\hline 5 & James Canyon Creek ${ }^{3}$ & 1,300 & na & na & 1,325 & 0.98 \\
\hline 6 & Sierra Canyon Creek ${ }^{3}$ & 1,500 & na & 1,000 & 2,040 & 0.74 \\
\hline 7 & Genoa Canyon Creek ${ }^{3}$ & 960 & na & 900 & 1,415 & 0.68 \\
\hline 8 & Daggett Creek & 1,200 & 1,360 & 1,400 & 2,445 & 0.49 \\
\hline 9 & Mott Canyon Creek ${ }^{3}$ & 1,700 & na & 2,300 & 1,290 & 1.32 \\
\hline 10 & Monument Creek $^{3}$ & 2,600 & na & 2,300 & 1,515 & 1.72 \\
\hline 11 & Stutler Canyon Creek ${ }^{3}$ & 450 & na & 1,200 & 1,495 & 0.30 \\
\hline 12 & Sheridan Creek $^{3}$ & 1,300 & na & 900 & 645 & 2.02 \\
\hline 13 & Jobs Canyon Creek ${ }^{3}$ & 1,700 & na & 1,800 & 2,015 & 0.84 \\
\hline 14 & Miller Spring & 632 & 633 & na & indeterminate & na \\
\hline 16 & Fredericksburg Canyon Creek & 2,890 & 3,230 & 4,700 & 2,375 & 1.22 \\
\hline & Total: West side & 24,500 & na & na & 21,125 & ${ }^{4} 1.13$ \\
\hline 19 & Pine Nut Creek & 665 & 918 & na & 6,390 & 0.10 \\
\hline 20 & Buckeye Creek & 692 & 645 & na & 29,155 & 0.02 \\
\hline & Total: East side & 1,360 & na & na & 35,545 & 0.04 \\
\hline & Total: Perennial stream inflow & 25,900 & na & 18,400 & 56,670 & 0.45 \\
\hline \multicolumn{7}{|c|}{ Ephemeral drainages } \\
\hline Ephemeral c & ainages above valley floor, western side & 8,100 & na & na & 14,200 & 50.57 \\
\hline Ephemeral c & ainages above valley floor, eastern side & 3,600 & na & na & 89,000 & ${ }^{6} 0.04$ \\
\hline Total: $\mathbf{E}_{\mathbf{I}}$ & emeral inflow & 11,700 & na & 6,000 & 103,200 & 0.11 \\
\hline & TOTAL: All tributary inflow & 37,600 & na & 24,000 & 159,870 & $\mathbf{0 . 2 3}$ \\
\hline \multicolumn{7}{|c|}{ Mainstem Carson River } \\
\hline 17 & West Fork Carson River & 75,150 & ${ }^{7} 80,320$ & na & ${ }^{7} 41,860$ & 1.80 \\
\hline 18 & East Fork Carson River & 257,000 & ${ }^{7} 276,400$ & na & ${ }^{7} 227,840$ & 1.13 \\
\hline
\end{tabular}

${ }^{1}$ Computed flow rounded to three significant figures, estimated flow rounded to two significant figures.

${ }^{2}$ Computed or estimated annual flow 1990-2002 divided by drainage area, unless otherwise noted.

${ }^{3}$ Annual flow estimated from regression equations.

${ }^{4}$ Calculated using total flow on western side minus flow of Miller Spring.

${ }^{5}$ Half of unit-area flow for perennial streams on western side because most drainages do not extend to top of Carson Range.

${ }^{6}$ Unit-area flow for perennial streams on eastern side.

${ }^{7}$ From Berris and others (2003). 
feet, by dividing by the area, in acres, of each drainage. These values were used to estimate tributary inflow from ephemeral drainages on the western and eastern sides of Carson Valley.

\section{UPDATED COMPUTATIONS AND ESTIMATES OF STREAMFLOWS TRIBUTARY TO CARSON VALLEY}

The computations and estimates of mean annual flow of perennial streams tributary to Carson Valley show estimated inflow for the period 1990-2002 totaled about 25,900 acre-ft/yr (fig. 6, table 3). The inflow includes 6 streams with continuously recording gages and estimates for 10 ungaged drainages, representing all perennial streams tributary to the valley. Inflow computed from gaged drainages totals 10,300 acre-ft/yr, and inflow estimated from ungaged drainages totals about 15,600 acre-ft/yr. These drainages have a total area of about 56,670 acres; 21,125 acres cover the western side of the valley and 35,545 acres cover the eastern side (table 3 ).

Mean annual flow for the period 1990-2002 is within about 10 percent of the flow computed for the entire period of record at most gaged drainages (table 3). Mean flow for Pine Nut Creek is about 30 percent greater for the entire period of record than for 1990-97. With the exception of Clear and Buckeye Creeks, mean flows for all other streams computed for the entire period of record are greater than those computed for 1990-2002. This indicates that the period 1990-2002 was somewhat drier than normal. Figure $7 A$ graphically shows the difference in the mean annual flow of the East Fork of the Carson River for the period 1939-2002 and for 1990-2002.

As stated previously, the 1971-2000 average annual precipitation at Minden, NV, was $8.38 \mathrm{in} / \mathrm{yr}$ (National Oceanic and Atmospheric Administration, 2002, p. 12) and is nearly the same as average annual precipitation for the period 1990-2002 at $8.45 \mathrm{in} / \mathrm{yr}$ (fig 7B; Western Regional Climate Center, 2003). Similarly, the average annual precipitation for 1971-2000 at Heavenly Valley, CA, is $32.9 \mathrm{in} / \mathrm{yr}$ (Chris Pacheco, Natural Resources Conservation Service, oral commun., 2003), and the average for 1990-2002 is $33.3 \mathrm{in} / \mathrm{yr}$ (Natural Resources Conservation Service, 2004). Heavenly Valley is near the crest of the Carson Range near the Mott Canyon Creek drainage (site 9; fig. 2). Thus, from available data near the floor of Carson Valley and the crest of the Carson Range, precipitation for the period 1990-2002 was not significantly different than for the period 1971-2000.

Although precipitation averages are about equal for 19712000 and 1990-2002, conditions during 1990-2002 were quite variable. Prior to the early 1980's, precipitation generally fluctuated almost annually from above normal to below normal with relatively few periods of extended above or below normal conditions. Following two extremely wet years in 1982 and 1983 , conditions fluctuated from generally below average for 1984-92 to above average for 1993-98 and below average for
1998-2002 (fig. 7B). Flow of the East Fork Carson River generally has followed the trends in annual precipitation (fig. $7 A$ ). Because of the extended periods of below and above normal precipitation from 1990-2002, it may be largely fortuitous that average precipitation for that period is similar to the 1971-2000 average.

The annual flow of perennial streams ranges from 4,210 acre-ft/yr at Clear Creek to 450 acre-ft/yr at Stutler Canyon Creek (fig. 6, table 3). The drainage area for Clear Creek is by far larger than any other in the Carson Range tributary to Carson Valley (table 1). However, the drainage area for Stutler Canyon Creek is quite similar to other drainages. Similarly, the drainage areas for Pine Nut and Buckeye Creeks are quite large compared to streams draining the Carson Range, yet mean annual flow is relatively small.

For a more direct comparison, annual unit-area runoff for the drainages, in feet, was calculated by dividing the computed or estimated annual flow, in acre-feet, by the area of the drainages, in acres (table 3). Annual unit-area runoff for streams draining the Carson Range ranges from $0.30 \mathrm{ft}$ for Stutler Canyon to $2.02 \mathrm{ft}$ for Sheridan Creek. Unit-area runoff for Pine Nut and Buckeye Creeks draining the Pine Nut Mountains is much less, 0.1 and $0.02 \mathrm{ft}$, respectively. This difference likely is caused by the rain-shadow effect of the Sierra Nevada, which decreases the amount of annual precipitation in the Pine Nut Mountains.

Variations in the seasonal distribution of inflow are apparent from the graphs of mean monthly flow shown in the appendix. On the East and West Forks and mainstem of the Carson River, monthly flows are greatest during spring runoff, generally in May and June. Similar flow distributions are seen for Water Canyon, James Canyon, Sierra Canyon, Daggett, Luther, Fredericksburg, and Pine Nut Creeks. Monthly flows are greatest during winter months, typically December through March, at Clear, Genoa Canyon, Monument Canyon, Jobs Canyon and Buckeye Creeks. At Miller Spring, flow is relatively uniform, but greatest during late summer and fall with lowest flows during spring months. At Mott Canyon, Stutler Canyon, and Sheridan Creeks, flow also is relatively uniform throughout the year. These variations and variations in unit-area runoff likely are caused by differences in geologic setting, altitude, slope, or aspect of the individual drainages.

The remaining drainages tributary to Carson Valley are largely ephemeral and supply flow to the valley floor only during spring runoff in extremely wet years or during large precipitation events. The area of ephemeral drainages above the valley floor (about 4,800 ft above sea level) totals about 14,200 acres on the western side of the valley and 89,000 acres on the eastern side (fig. 2, table 3). Many of the ephemeral drainages do not extend to the crest of the Carson Range on the western side of the valley, and ephemeral drainages cover large areas of low altitude on the eastern side of the valley.

On the western side of Carson Valley, annual unit-area runoff for the combined area of perennial drainages is $1.13 \mathrm{ft}$, excluding flow of Miller Spring which has an indeterminate drainage area (table 3). Because the ephemeral drainages on the 
$A$

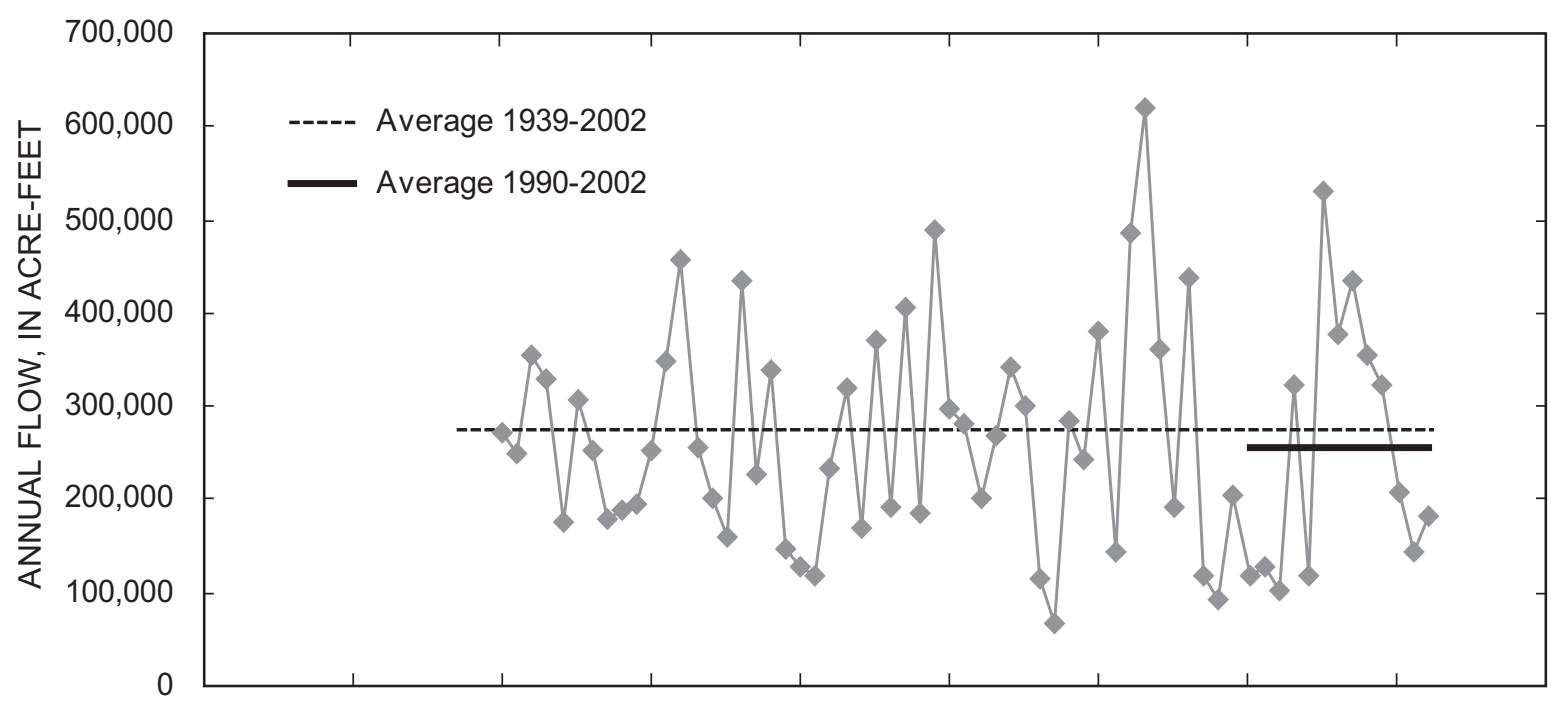

$B$

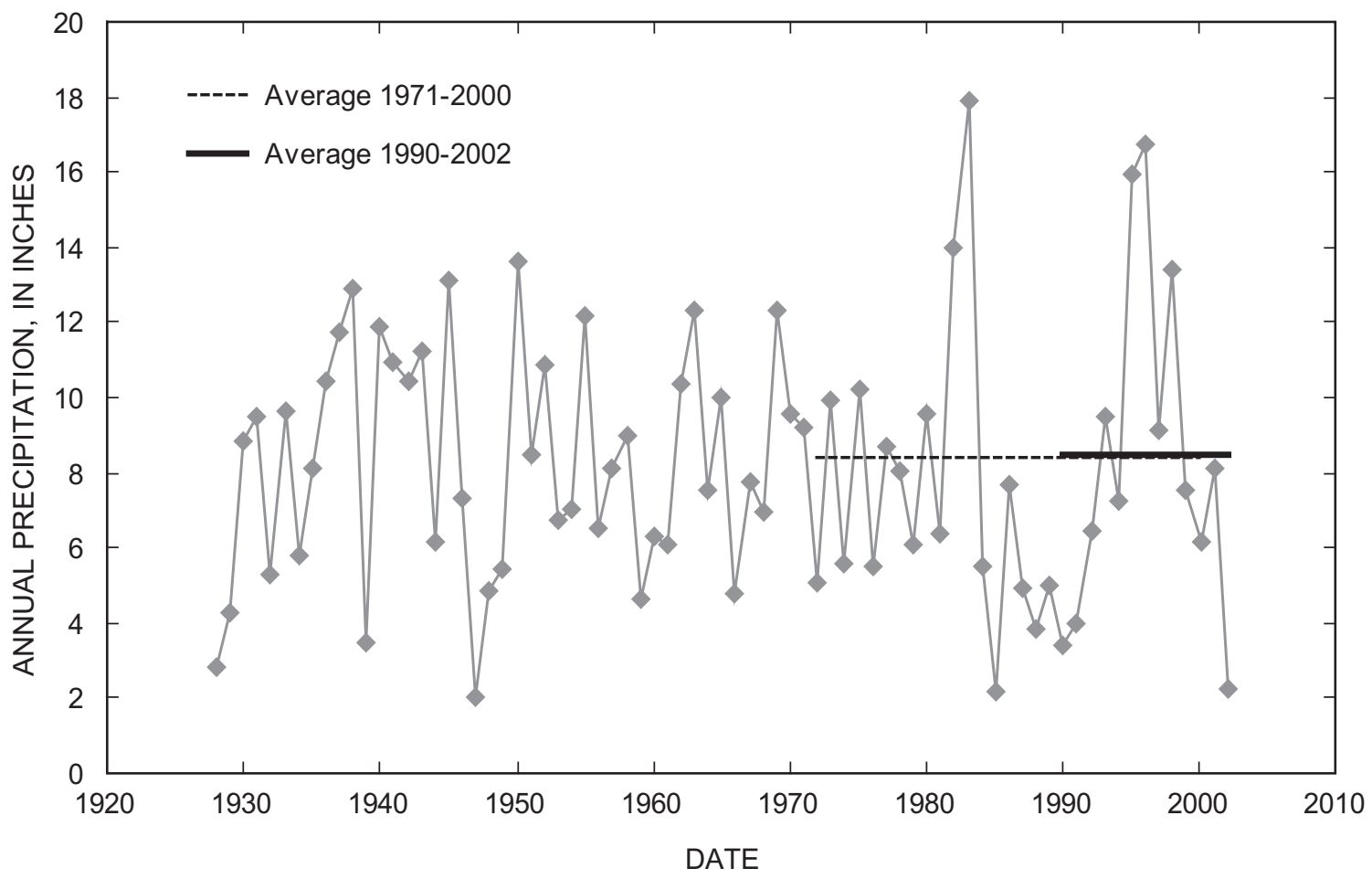

Figure 7. (A) Annual flow of the East Fork Carson River near Gardnerville, Nevada, and average annual flow for 1939-2002 and 1990-2002 and (B) annual precipitation at Minden, Nevada, for period of record and average annual precipitation for 1971-2000 and 1990-2002. 
western side of the valley generally do not extend to the crest of the Carson Range, a reasonable assumption may be that the unit-area runoff from these drainages is about half $(0.57 \mathrm{ft})$ that of the perennial drainages. This value is less than those for most perennial drainages on the western side of the valley, but greater than three drainages: Clear, Daggett, and Stutler Canyon Creeks (table 3). Applying a unit-area runoff of $0.57 \mathrm{ft}$ to the 14,200 acres of ephemeral drainages results in an estimate of about 8,100 acre-ft/yr for 1990-2002 (table 3).

On the eastern side of Carson Valley, annual unit-area runoff for the combined area of Pine Nut and Buckeye Creeks is $0.04 \mathrm{ft}$ (table 3). These drainages cover areas of relatively high altitude along the crest of the Pine Nut Mountains (fig. 2). Ephemeral drainages on the eastern side of the valley cover only a small part of the crest of the Pine Nut Mountains, with the remainder at relatively low altitudes, indicating a relatively low unit-area runoff may be applicable. However, streamflow from the ephemeral drainages generally is not derived from snowmelt runoff but usually occurs during intense summer thunderstorms, generating large peak flows, but of a very short duration. Peak flows as great as 1,400 and $3,000 \mathrm{ft}^{3} / \mathrm{s}$ have been estimated for ungaged drainages on the northeastern side of the valley (Berris and others, 2003, p. 420), indicating a relatively high unit-area runoff may be applicable. For these reasons, a unit-area runoff of $0.04 \mathrm{ft}$ may provide a reasonable average value for the ungaged ephemeral drainages. Applying an annual unit-area runoff of $0.04 \mathrm{ft}$ to the 89,000 acres of ephemeral drainages results in an estimate of about 3,600 acre-ft/yr (table 3 ). Total ephemeral inflow from the eastern and western sides of the valley is $11,700 \mathrm{acre}-\mathrm{ft} / \mathrm{yr}$.

Combining the estimates of ephemeral inflow with the computed and estimated inflows from gaged and ungaged perennial drainages results in a total tributary inflow of about $37,600 \mathrm{acre}-\mathrm{ft} / \mathrm{yr}$ (table 3). Gaged perennial inflow is 27 percent of the total, ungaged perennial inflow is 42 percent, and ephemeral inflow is 31 percent.

Comparison of the estimate of total tributary inflow with previous estimates is difficult because previous work often covered different areas. The estimate of $37,600 \mathrm{acre}-\mathrm{ft} / \mathrm{yr}$ is about 50 percent greater than that of Piper $(1969$, p. 7) who estimated 24,800 acre-ft/yr for an area including the Clear and Indian Creeks drainages. The estimate also is about 60 percent greater than that of Maurer (1986, p. 37), 24,000 acre-ft/yr, who did not include flow from Water Canyon, James Canyon, Sheridan Canyon, Pine Nut, and Buckeye Creeks; and the Nevada State Engineer (1971, p. 57), 24,000 acre-ft/yr for a similar area. The estimate is similar to the 34,000 and 42,000 acre-ft/yr estimated by Glancy and Katzer (1976, p. 34) and Spane (1977, p. 65-66), respectively. However, the studies of Glancy and Katzer and Spane covered larger areas.

Comparison of the estimated flow for individual streams made previously by Maurer (table 3; 1986, p. 15) shows estimates at most streams increased with the exception of Sierra, Genoa, and Monument Creeks. Estimates increased from 10 to as much as 60 percent for Stutler Canyon Creek. Estimates for
Sierra, Genoa, and Monument Creeks decreased from about 6 to 40 percent. Estimates made by Maurer (1986) were based on relatively few measurements made during 1981-83.

\section{Uncertainty of Estimates}

The uncertainty associated with the estimates of perennial tributary inflow may be approximated from the descriptions of records for gaged streams. The uncertainty of the estimates of ungaged perennial and ephemeral inflow is more difficult to determine.

Descriptions of records for gaged streams are good at Clear and Daggett Creeks, fair at Pine Nut and Buckeye Creeks and mainstem Carson River gages, and poor at Fredericksburg Canyon Creek and Miller Spring (Berris and others, 2003, p. 178, 185-186, and 190-191; Allander and others, 2001, p. 163; Bonner and others, 1998, p. 147-148 and 153). Records described as good, fair, and poor have accuracies within 10, 15, and greater than 15 percent, respectively (Berris and others, 2003 , p. 21). The combined accuracy of gaged data may be reasonably approximated by an overall value of about 15 percent. Applying this percentage to the total 10,300 acre-ft/yr of gaged inflow an uncertainty of about $1,500 \mathrm{acre}-\mathrm{ft} / \mathrm{yr}$ is obtained or about 4 percent of the total tributary inflow.

The uncertainty of the estimates for ungaged perennial inflow, in part, depends on the number and distribution of streamflow measurements during 1990-2002 used to develop the regression equations. Genoa Canyon and Jobs Canyon Creeks have the greatest number of measurements, distributed over the entire 12-year period (table 2). However, the percent error for the regression equation developed for Jobs Canyon Creek is large ( 92 percent). The remaining drainages have fewer measurements and the measurements were made either over the first part or last part of the 12-year period. The percent error for regression equations developed for these drainages ranges from 21 to 57 percent. However, the percent error values apply only to the daily mean flows estimated for the days of measurement on the ungaged drainages, and cannot be directly applied to the entire series of estimated daily mean flows. A reasonable maximum uncertainty of the estimates of inflow from ungaged perennial drainages may be about 30 percent of their total $15,600 \mathrm{acre}-\mathrm{ft} / \mathrm{yr}$ or about 5,000 acre-ft/yr. This volume is about 13 percent of the total tributary inflow.

A large amount of uncertainty is associated with the estimate of 11,700 acre-ft/yr of flow from ephemeral drainages in Carson Valley. However, the lack of streamflow data from these drainages precludes more accurate estimates. Varying the annual unit-area runoff for ephemeral drainages on the western side of the valley from 0.30 to $1.0 \mathrm{ft}$, the range for most perennial drainages, results in a range of 4,200 and 14,200 acre$\mathrm{ft} / \mathrm{yr}$. Similarly, for ephemeral drainages on the eastern side of the valley, varying the annual unit-area runoff from 0.02 to 0.1 , the values for Buckeye and Pine Nut Creeks, respectively, results in a range of 1,800 and 8,900 acre-ft/yr. Combining these ranges results in estimates of total ephemeral flow from 
6,000 to 23,000 acre- $\mathrm{ft} / \mathrm{yr}$. The value of $23,000 \mathrm{acre}-\mathrm{ft} / \mathrm{yr}$ is unreasonably high given the relatively low altitude of the ephemeral drainages. A more reasonable estimate for the range in ephemeral inflow is from 6,000 to $18,000 \mathrm{acre}-\mathrm{ft} / \mathrm{yr}$. Thus, the uncertainty in estimates of ephemeral inflow is plus or minus 6,000 acre-ft/yr, about 50 percent of the total 11,700 acre-ft/yr, or 16 percent of the total tributary inflow. Combining the uncertainty of inflow from gaged, ungaged, and ephemeral drainages results in a total of 33 percent of the total tributary inflow or about 12,000 acre-ft/yr.

\section{SUMMARY AND CONCLUSIONS}

To address concerns over continued availability of water resources in Carson Valley, the USGS, in cooperation with Douglas County, began a study in 2003 to update estimates of water-budget components in Carson Valley to reflect current climatic conditions. Streamflow data were collected at 9 continuously recording streamflow gages and at 10 sites in ungaged drainages where 408 measurements were made. Data collected at these sites were compiled and analyzed to provide updated computations and estimates of tributary streamflows and Carson River outflow from the valley for the period 1990-2002.

Mean monthly and annual flows were computed from continuous records for the period 1990-2002 for five streams, and for the period available, 1990-97, for four streams. Multivariate regression equations were developed to estimate daily mean streamflows at the 10 perennial but ungaged drainages using the continuous flow record at selected gaged sites. The estimated daily mean flows for each of the 10 ungaged drainages from 1990 to 2002 were used to calculate monthly and annual mean flows for each month and year, and mean monthly and annual flow for the period 1990-2002.

For the period 1990-2002, the computations and estimates of mean annual flow of perennial streams tributary to Carson Valley indicate estimated inflow totaled about 25,900 acre$\mathrm{ft} / \mathrm{yr}$. Inflow computed from gaged perennial drainages totals $10,300 \mathrm{acre}-\mathrm{ft} / \mathrm{yr}$, and inflow estimated from ungaged perennial drainages totals 15,600 acre-ft/yr. The remaining drainages are ephemeral and supply flow to the valley floor only during spring runoff in wet years or during large precipitation events.

Mean annual flow for the period 1990-2002 is within about 10 percent, but less than flow computed for the entire period of record at most of the six gaged drainages. This indicates that the period 1990-2002 was somewhat drier than normal. From available data near the floor of Carson Valley and the crest of the Carson Range, it appears that precipitation for the period 1990-2002 was not significantly different than for the period 1971-2000. However, prior to the early 1980's, precipitation generally fluctuated almost annually from above normal to below normal with relatively few periods of extended above or below normal conditions. After the early 1980's, conditions fluctuated from generally below average for 198492 to above average for 1993-98 and below average for 1998-
2002. Because of the extended periods of below and above normal precipitation from 1990-2002, it may be largely fortuitous that average precipitation for that period is similar to the 1971-2000 average.

The annual flow of perennial streams ranges from 4,210 acre-ft/yr at Clear Creek to 450 acre-ft/yr at Stutler Canyon Creek. Calculated annual unit-area runoff for the drainages in the Carson Range ranges from $0.30 \mathrm{ft}$ for Stutler Canyon to 2.02 $\mathrm{ft}$ for Sheridan Creek. Unit-area runoff for Pine Nut and Buckeye Creeks draining the Pine Nut Mountains is much less, 0.1 and $0.02 \mathrm{ft}$, respectively. The difference, likely is caused by the rain-shadow effect of the Sierra Nevada, which decreases the amount of annual precipitation in the Pine Nut Mountains.

On the mainstem of the Carson River and at Water Canyon, James Canyon, Sierra Canyon, Daggett, Luther, Fredericksburg, and Pine Nut Creeks, monthly flows are greatest during spring runoff, generally in May and June. Monthly flows are greatest during winter months, typically December through March, at Clear, Genoa Canyon, Monument Canyon, Jobs Canyon, and Buckeye Creeks. At Miller Spring and Mott Canyon, Stutler Canyon, and Sheridan Creeks, flow is relatively uniform throughout the year. Streamflow variations and variations in unit-area runoff likely are caused by differences in geologic setting, altitude, slope, or aspect of the individual drainages.

The area of ephemeral drainages above the valley floor totals about 14,200 acres on the western side of the valley and 89,000 acres on the eastern side. Many of the ephemeral drainages on the western side of the valley do not extend to the crest of the Carson Range, and on the eastern side of the valley, cover large areas of low altitude. On the western side of the valley, applying an annual unit-area runoff half of that for perennial streams, $0.57 \mathrm{ft}$, results in an estimate of about 8,100 acre-ft/yr for inflow from the ephemeral drainages. On the eastern side of the valley, applying an annual unit-area runoff for the combined area of Pine Nut and Buckeye Creeks, $0.04 \mathrm{ft}$, results in an estimate of about 3,600 acre-ft/yr for inflow from the ephemeral drainages. Total estimated ephemeral inflow is 11,700 acre$\mathrm{ft} / \mathrm{yr}$.

Combining the estimates of inflow from ephemeral drainages with the computed and estimated inflows from perennial drainages results in a total tributary inflow of about 37,600 acre$\mathrm{ft} / \mathrm{yr}$. Gaged perennial inflow is 27 percent of the total, ungaged perennial inflow is 42 percent, and ephemeral inflow is 31 percent. Comparison of the estimate of tributary flow with previous estimates is difficult because previous work covered different areas. The estimate of 37,600 acre-ft/yr is from 50 to 60 percent greater than three previous estimates, one made for a larger area and similar to two other estimates made for larger areas.

The uncertainty associated with the estimates of inflow from perennial drainages was approximated from the descriptions of records for gaged streams to be about 15 percent; 1,500 acre-ft/yr of their total or 4 percent of the total inflow. The uncertainty associated with estimates of ungaged perennial inflow is about 30 percent; 5,000 acre-ft/yr of their total or 
about 13 percent of total inflow. The uncertainty of inflow from ephemeral drainages, estimated by applying a range of annual unit-area runoff values to their areas on the western and eastern sides of the valley, was 6,000 acre-ft/yr; 50 percent of their total or about 13 percent of the total inflow. The resulting uncertainty of gaged, ungaged, and ephemeral tributary inflows is about 33 percent of the total 37,600 acre-ft/yr or about 12,000 acre-ft/yr.

\section{REFERENCES CITED}

Allander, Kip, Gortsema, Gary, Hutchinson, Douglas, and Schwartzenberger, James, 2001, Water Resources Data Nevada Water Year 2000: U.S. Geological Survey WaterData Report NV-00-1, 570 p.

Berris, S.N., Crompton, E.J., Joyner, J.D., and Ryan, Roslyn, 2003, Water Resources Data Nevada Water Year 2002: U.S. Geological Survey Water-Data Report NV-02-1, 600 p.

Bonner, L.J., Elliott, P.E., Etchemendy, L.P., and Swartwood, J.R., 1998, Water Resources Data Nevada Water Year 2000: U.S. Geological Survey Water-Data Report NV-97-1, 636 p.

Cardinalli, J.L., Roach, L.M., Rush, F.E., and Vasey, F.J., comps., 1968, State of Nevada hydrographic areas: Nevada Division of Water Resources Bulletin 33, 162 p.

Economic Research Service, 2004, County-level population data for Nevada: Accessed on March 5, 2004, at URL $<$ http://www.ers.usda.gov/Data/Population/ Poplist.asp?ST= NV\&LongName $=$ Nevada $>$.

Glancy, P.A., and Katzer, T.L., 1976, Water-resources appraisal of the Carson River Basin, Western Nevada: Nevada Department of Conservation and Natural Resources, Water Resources-Reconnaissance Series, Report 59, 126 p.

Helsel, D.R., and Hirsch, R.M., 1992, Statistical methods in water resources: Studies in Environmental Science 49: Elsevier Science Publishing, New York, NY, 521 p.

Hess, G.W., 1999, Hydrologic data for water years 1978-97 used in daily flow-routing and river-operations models for the upper Carson River Basin, California and Nevada: U.S. Geological Survey Open-File Report 99-256, 16 p.

Maurer, D., K., 1986, Geohydrology and simulated response to ground-water pumpage in Carson Valley, a river-dominated basin in Douglas County, Nevada, and Alpine County, California: U.S. Geological Survey Water-Resources Investigations Report 86-4328, 109 p.

Maurer, D.K., and Peltz, L.A., 1994, Potential for, and possible effects of, artificial recharge in Carson Valley, Douglas County, Nevada: U.S. Geological Survey Water-Resources Investigations Report 94-4126, 4 sheets.
Moore, D.O., 1968, Estimating mean runoff in ungaged semiarid areas: Nevada Department of Conservation and Natural Resources, Water Resources Bulletin No. 36, 39 p.

National Oceanic and Atmospheric Administration, 2002, Monthly station normals of temperature, precipitation, and heating and cooling degree days, 1971-2000, Climatology of the United States, no. 81, Nevada: National Climatic Data Center, Asheville, NC, 26 p.

Natural Resources Conservation Service, 2004, Accumulated precipitation and monthly statistics: Accessed on January 20, 2004, at URL: <http://www.wcc.nrcs.usda.gov/ climate/avg/export.html>.

Nevada State Engineer, 1914, Cultural plat maps of Barber Canyon Creek: 1:7,200 scale, October 2, 1914, 2 sheets.

Nevada State Engineer, 1971, Nevada's water resources: Nevada Division of Water Resources, Water for Nevada Report 3, 87 p.

Piper, A.M., 1969, A water budget of the Carson Valley, Nevada: U.S. Geological Survey Professional Paper 417-F, 8 p.

Riggs, H.C., 1969, Mean streamflow from discharge measurements: Bulletin of the International Association of Scientific Hydrology, v. 24, no. 4, p. 95-110.

Rush, F.E., 1968, Index of hydrographic areas: Nevada Division of Water Resources, Information Report 6, 38 p.

SAS Institute, Inc., 1989, SAS/STAT User's Guide, version 6: Cary, NC, 4th ed., v. 2, 846 p.

SAS Institute, Inc., 1999, SAS OnlineDoc, version eight: Accessed on August 23, 2004, at URL: $<$ http://v8doc.sas.com/sashtml>.

Spane, F.A., 1977, Evaluation of factors influencing the inorganic water-quality regimen of Carson River, Carson Valley, Nevada-California: University of Nevada, Reno, Ph.D. thesis, $205 \mathrm{p}$.

Tasker, G.D., 1978, Relation between standard errors in log units and standard errors in percent: U.S. Geological Survey, WRD Bulletin, Jan-Mar - Apr-June 1978, p. 86-87.

U.S. Census Bureau, 2003, Census 2000 geographic comparison table: Accessed in December 2003, at URL: $<$ http://factfinder.census.gov>.

U.S. Department of Agriculture, 2004, 2002 Census of agriculture, Nevada, county summary highlights: Accessed on August 23, 2004, at URL:

$<$ http://www.nass.usda.gov/census $>$.

Western Region Climate Center, 2003, 1971-2000 Climate Summary: Accessed on August 23, 2004, for Minden at URL: <http://www.wrcc.dri.edu/cgi-bin/ cliMAIN.pl?nvmind>, and for Daggett Pass at URL: $<$ http://www.wrcc.dri.edu/cgi-bin/cliMAIN.pl?nvdagg>. 
20 Updated Computations and Estimates of Streamflows Tributary to Carson Valley, Douglas County, NV, and Alpine County, CA, 1990-2002 
Appendix: Graphs showing computed and estimated mean monthly flow for gaged and ungaged perennial streams tributary to Carson Valley, 1990-2002 
22 Updated Computations and Estimates of Streamflows Tributary to Carson Valley, Douglas County, NV, and Alpine County, CA, 1990-2002 
Clear Creek (site 2) - Computed

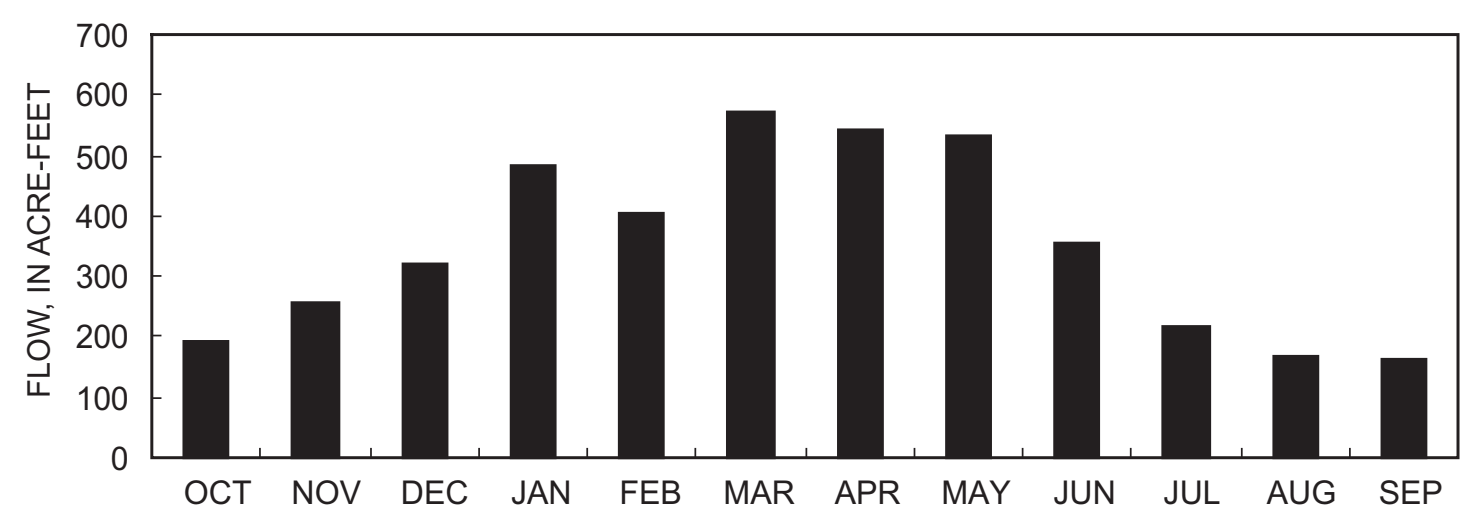

Water Canyon Creek (site 4) - Estimated

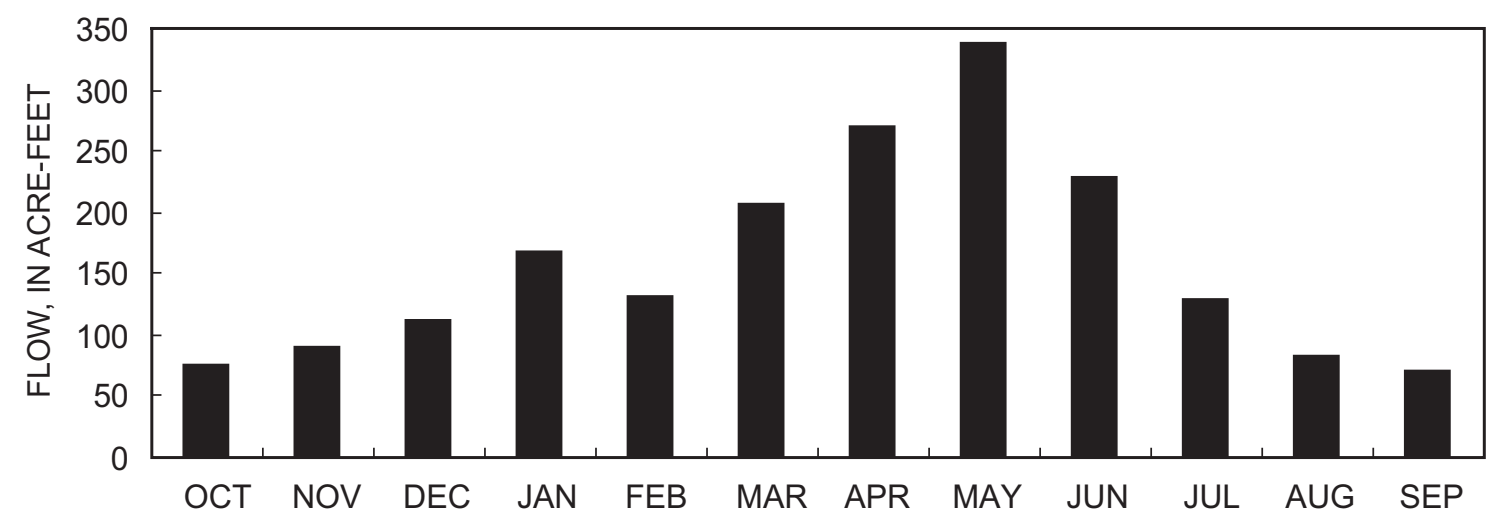

James Canyon Creek (site 5) - Estimated

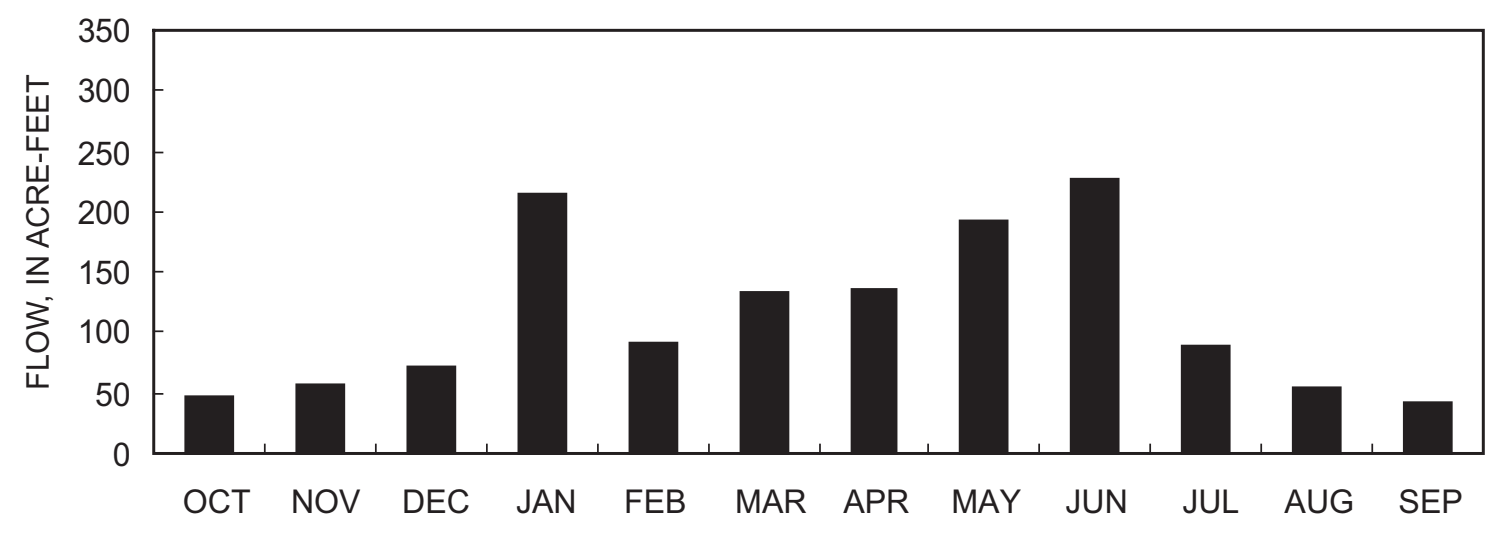

Appendix. Computed and estimated mean monthly flow for gaged and ungaged perennial streams tributary to Carson Valley, 1990-2002. See figure 2 for site locations. 
Sierra Canyon Creek (site 6) - Estimated

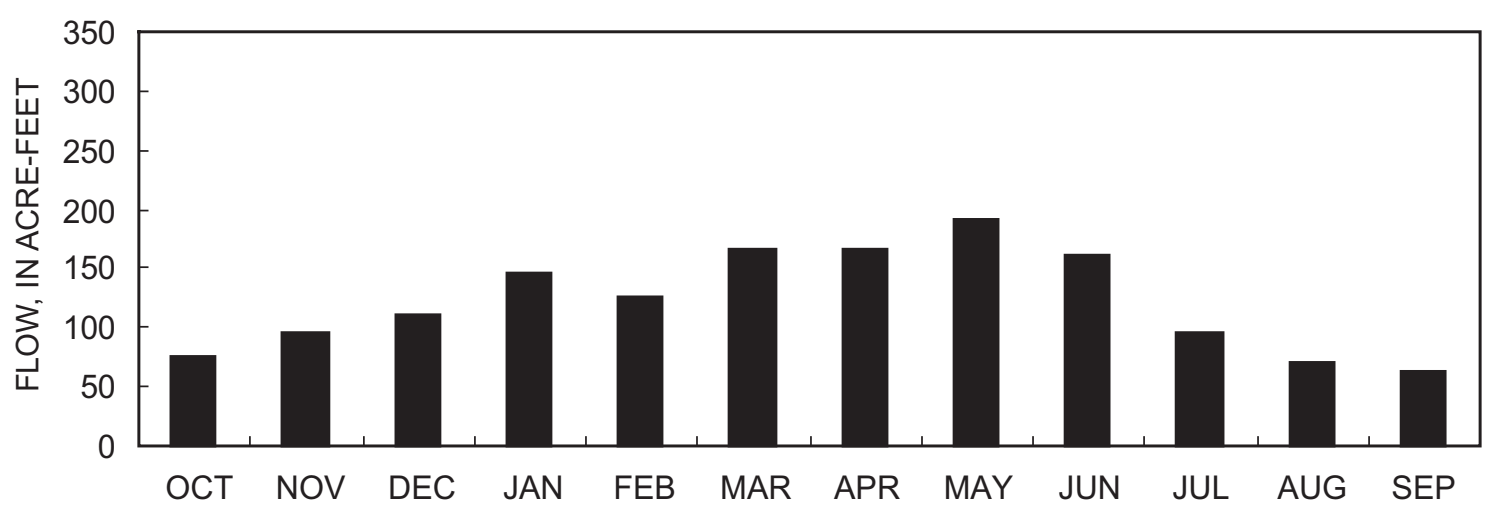

Genoa Canyon Creek (site 7) - Estimated

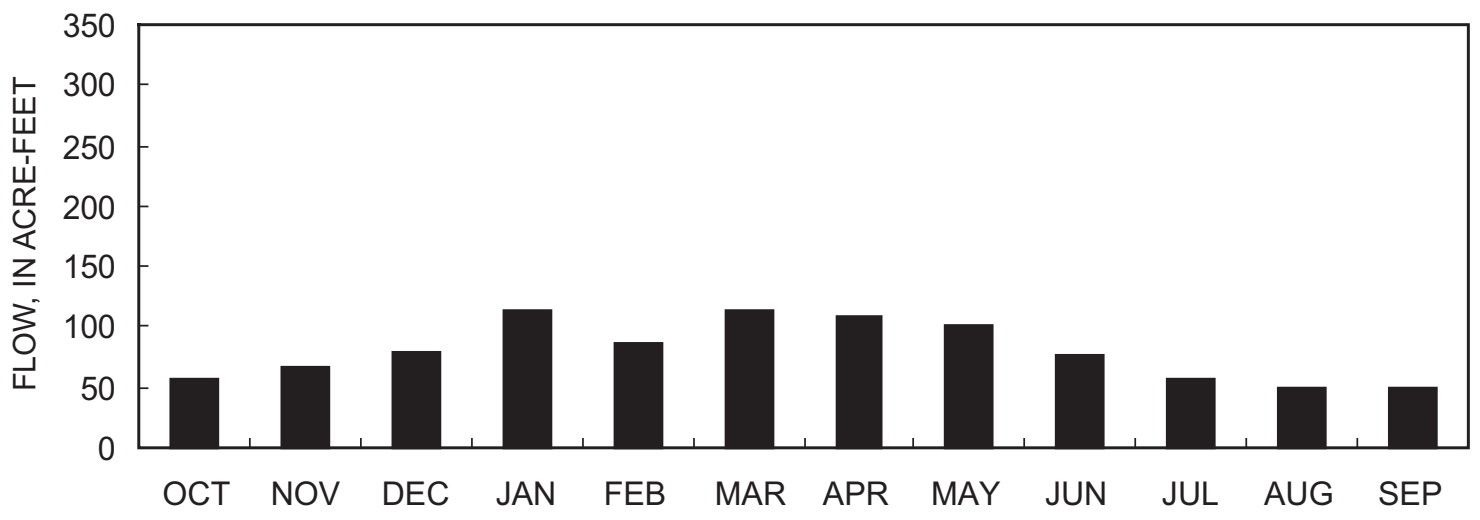

Daggett Creek (site 8) - Computed

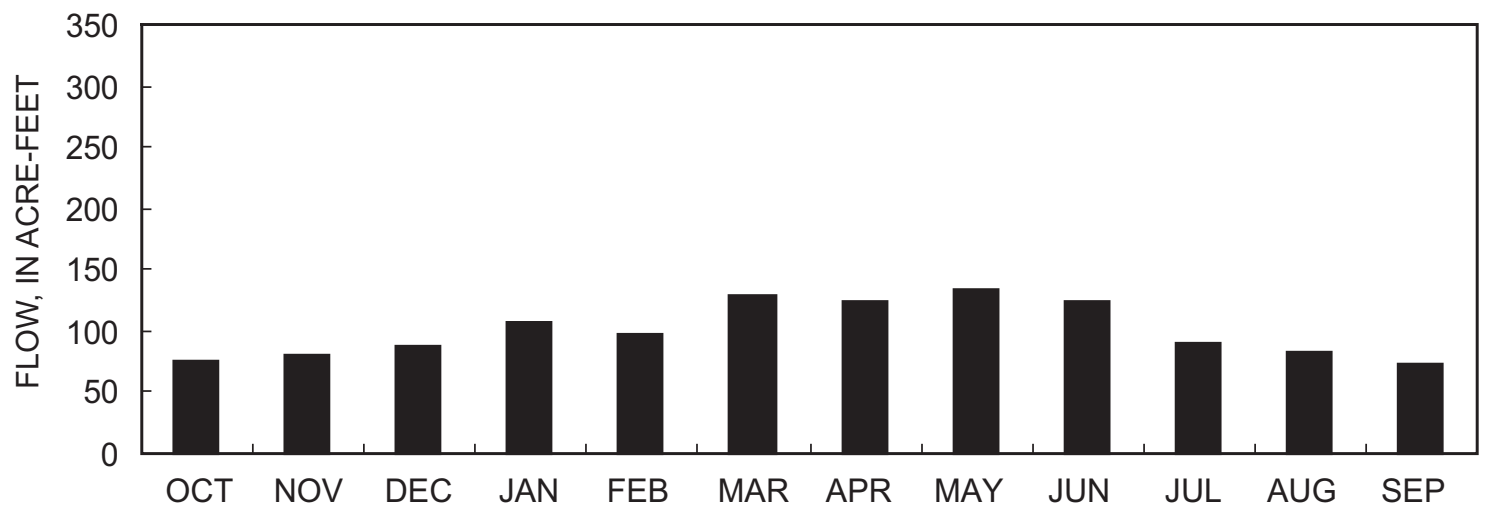

Appendix. Computed and estimated mean monthly flow for gaged and ungaged perennial streams tributary to Carson Valley, 1990-2002-Continued. 
Mott Canyon Creek (site 9) - Estimated

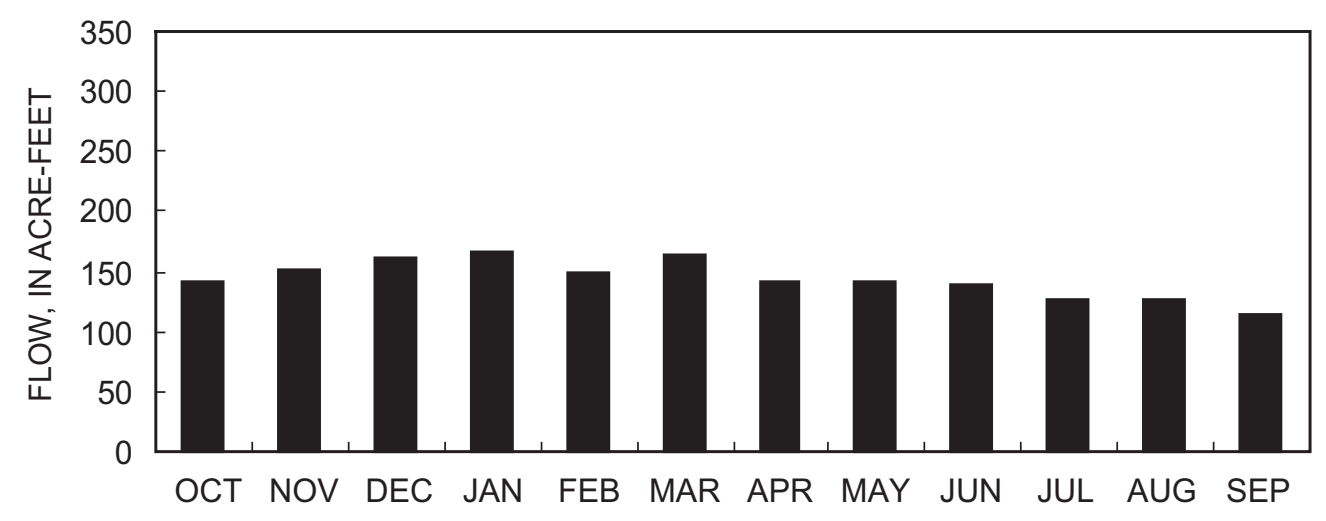

Monument Creek (site 10) - Estimated

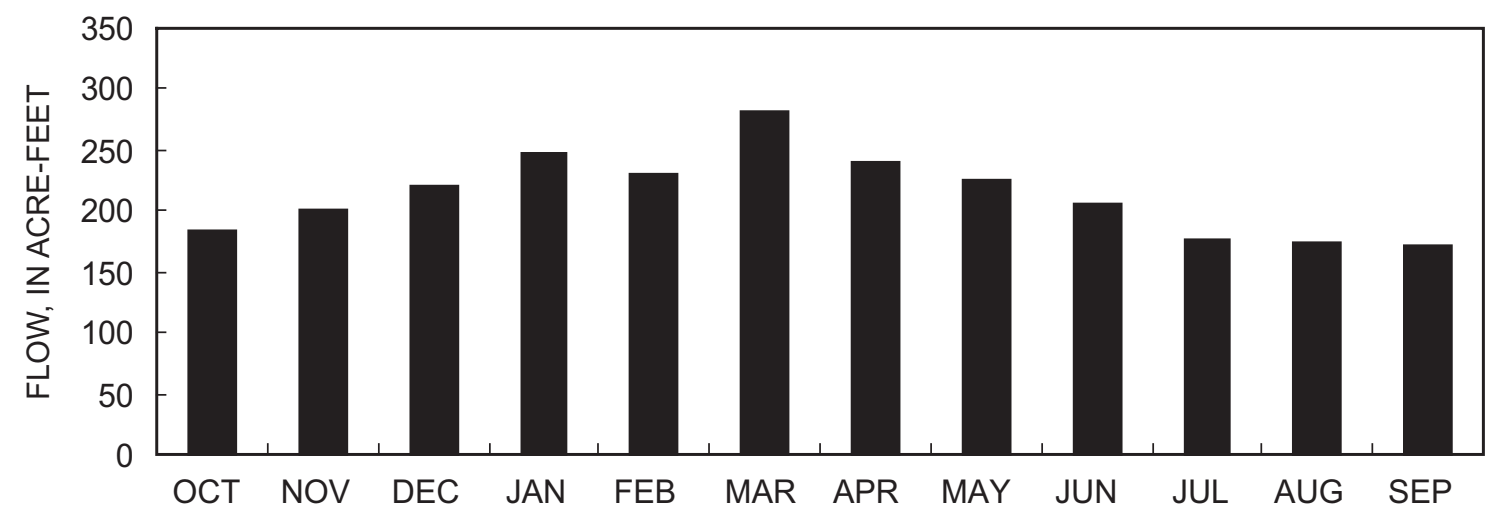

Stutler Canyon Creek (site 11) - Estimated

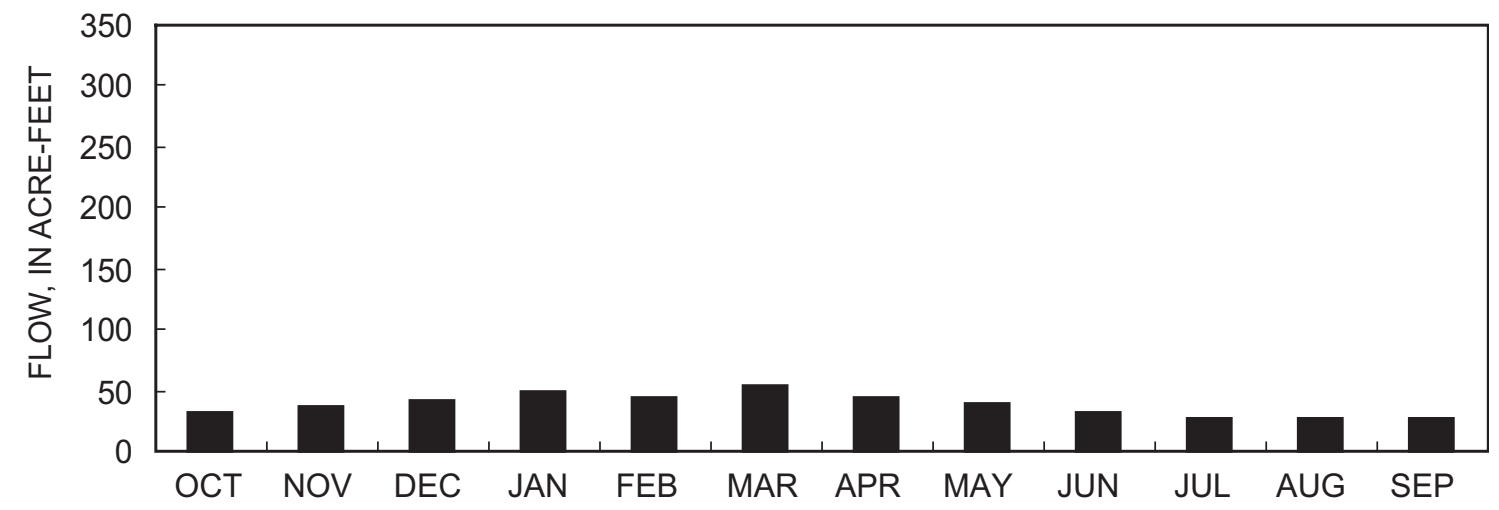

Appendix. Computed and estimated mean monthly flow for gaged and ungaged perennial streams tributary to Carson Valley, 1990-2002-Continued. 
Sheridan Creek (site 12) - Estimated

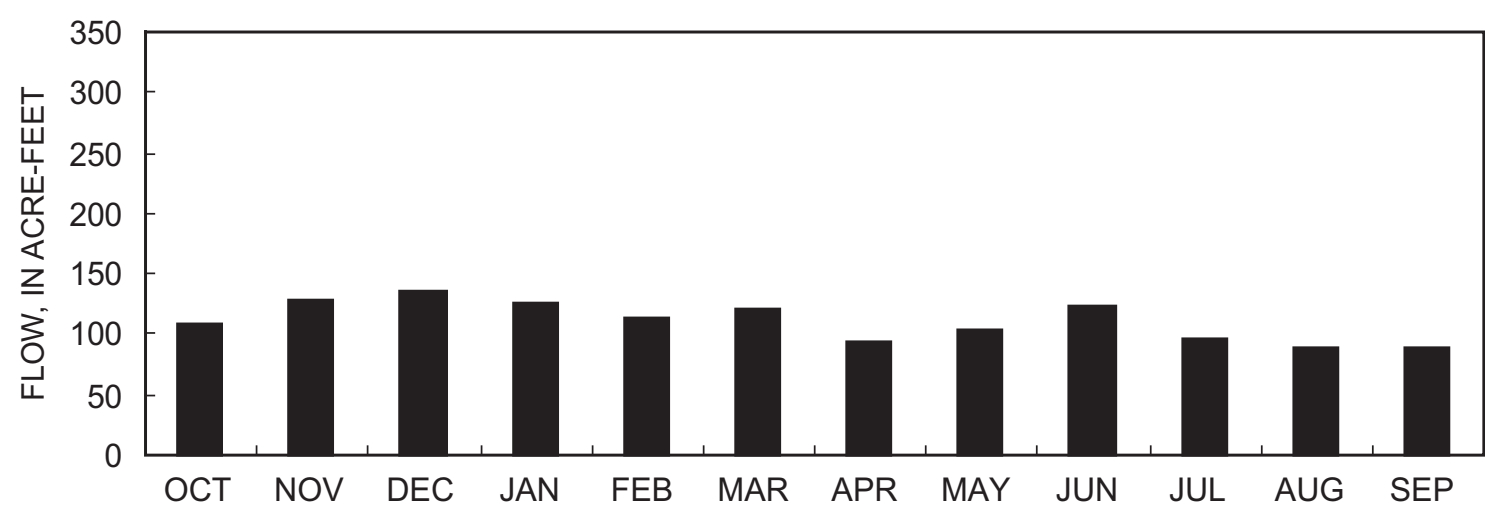

Jobs Canyon Creek (site 13) - Estimated

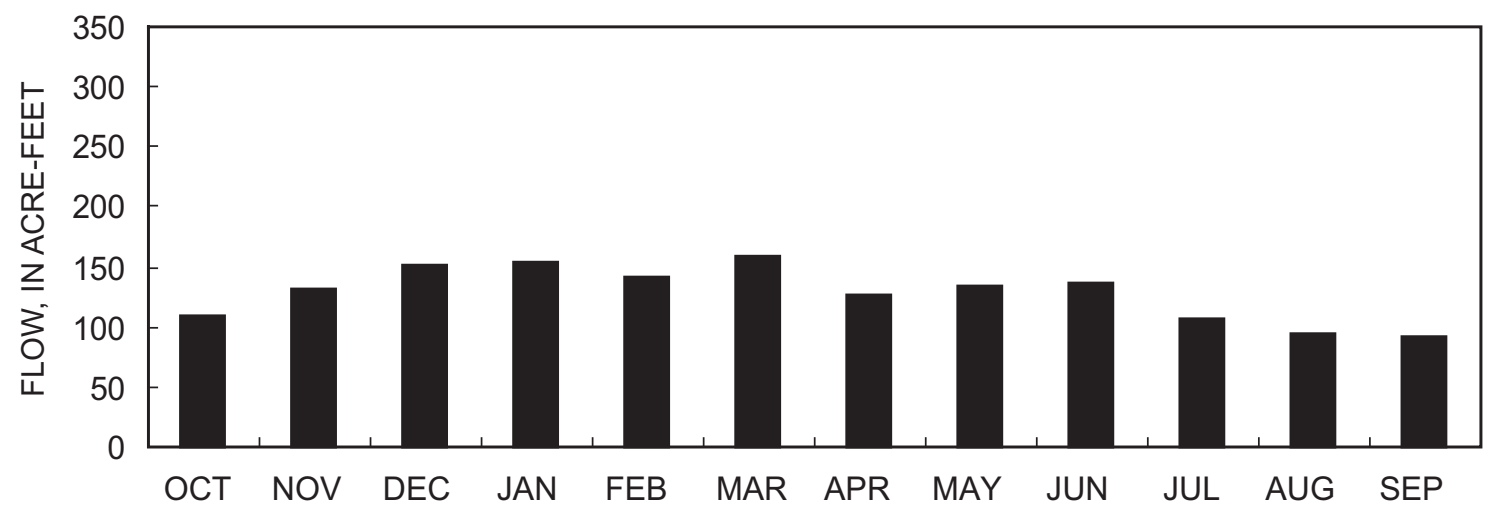

Miller Spring (site 14) - Computed

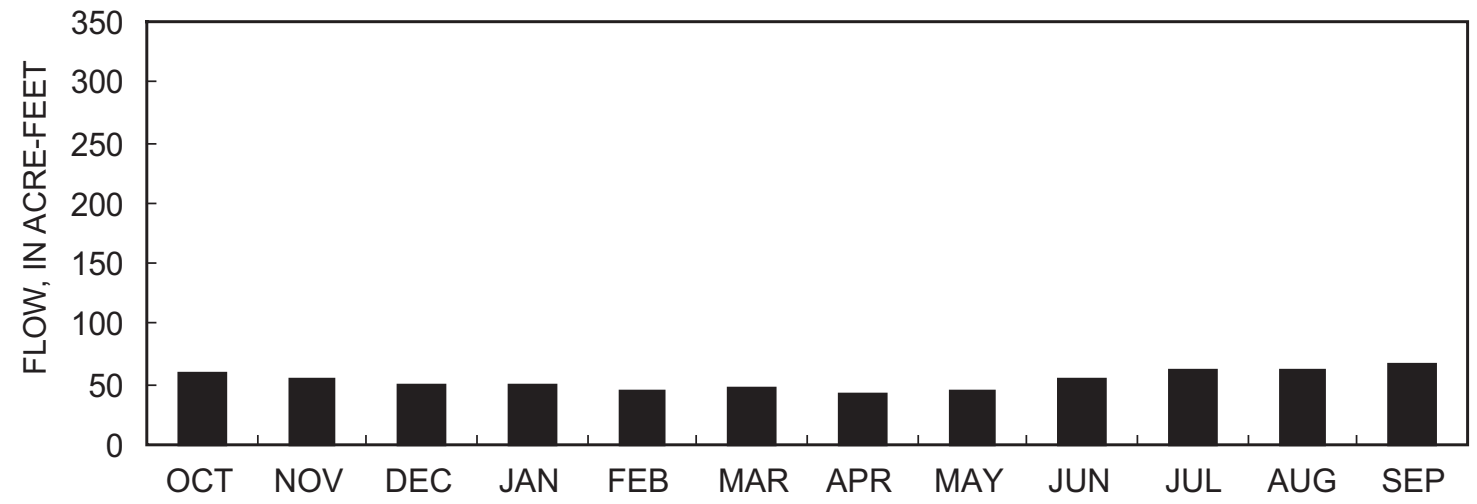

Appendix. Computed and estimated mean monthly flow for gaged and ungaged perennial streams tributary to Carson Valley, 1990-2002-Continued. 
Luther Creek (site 15) - Estimated

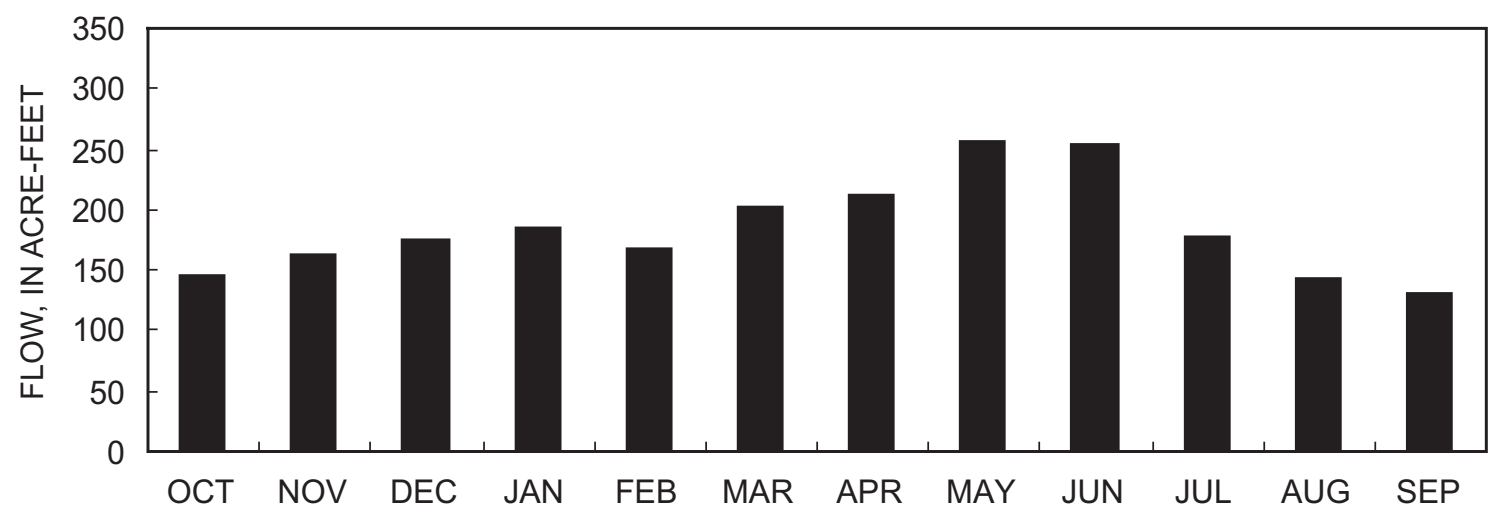

Fredericksburg Canyon Creek (site 16) - Computed

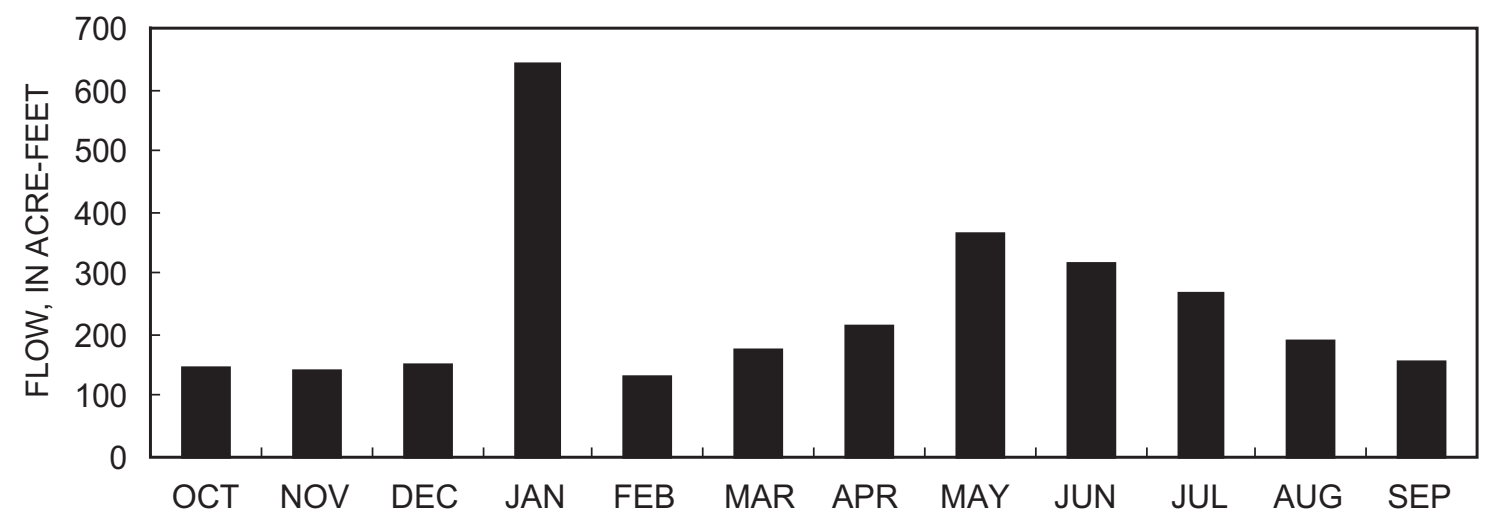

Pine Nut Creek (site 19) - Computed

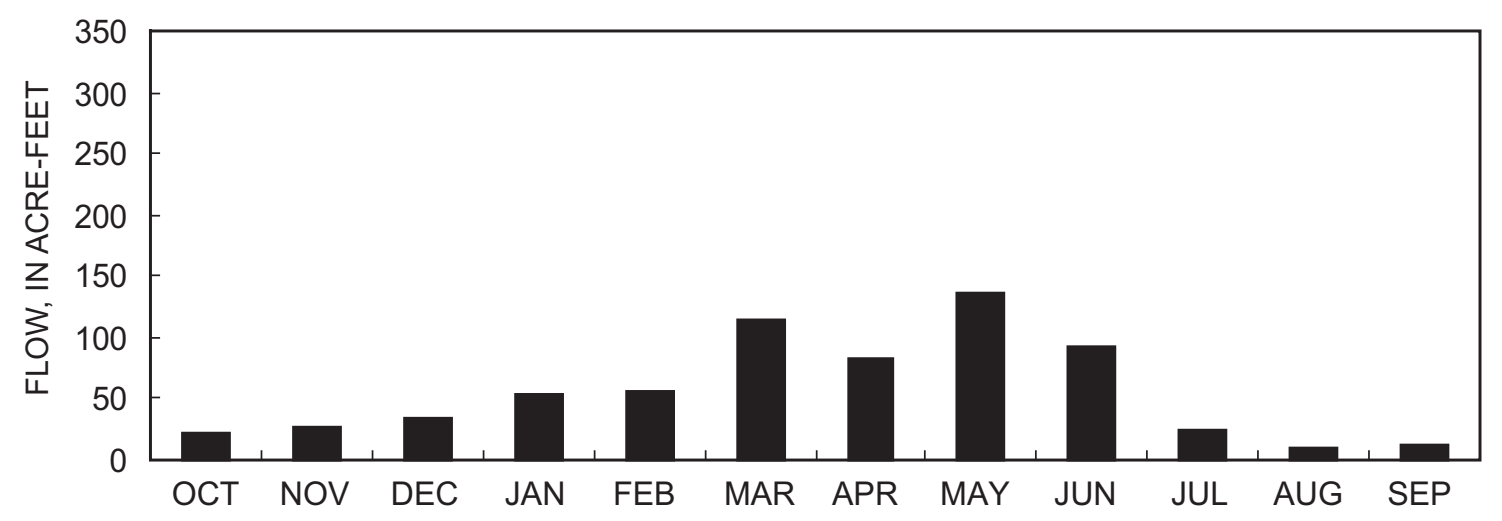

Appendix. Computed and estimated mean monthly flow for gaged and ungaged perennial streams tributary to Carson Valley, 1990-2002-Continued. 


\section{Buckeye Creek (site 20) - Computed}

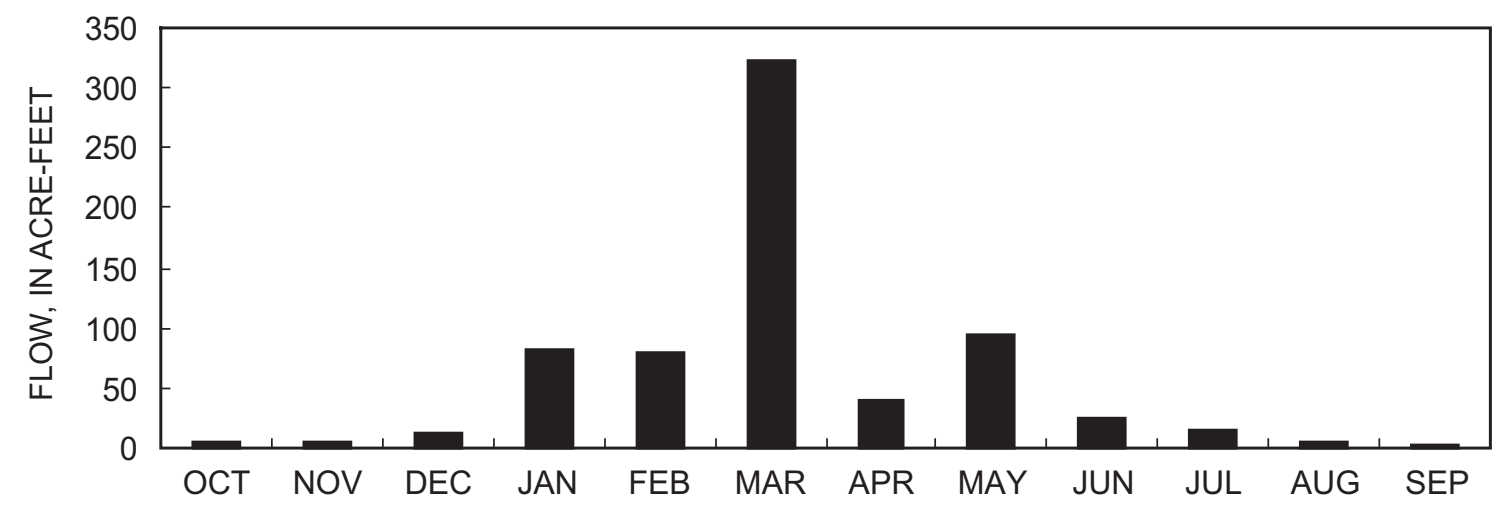

East Fork Carson River near Gardnerville, NV (site 18) - Computed

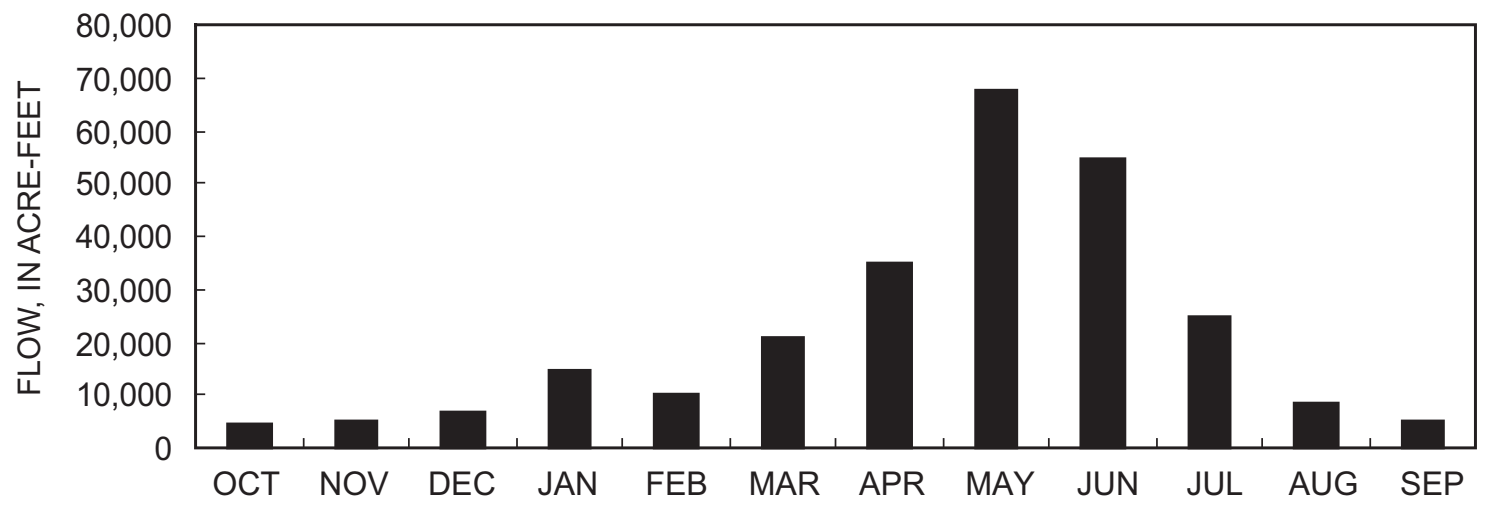

West Fork Carson River at Woodfords, CA (site 17) - Computed

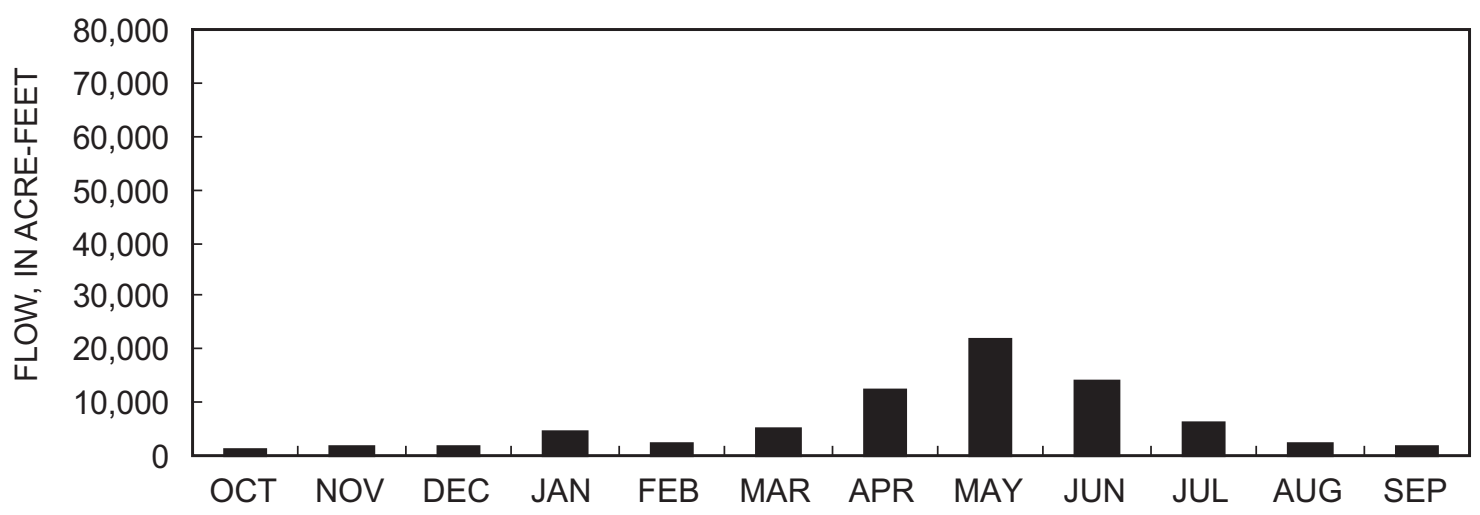

Appendix. Computed and estimated mean monthly flow for gaged and ungaged perennial streams tributary to Carson Valley, 1990-2002-Continued. 


\section{Carson River near Carson City, NV (site 3) - Computed}

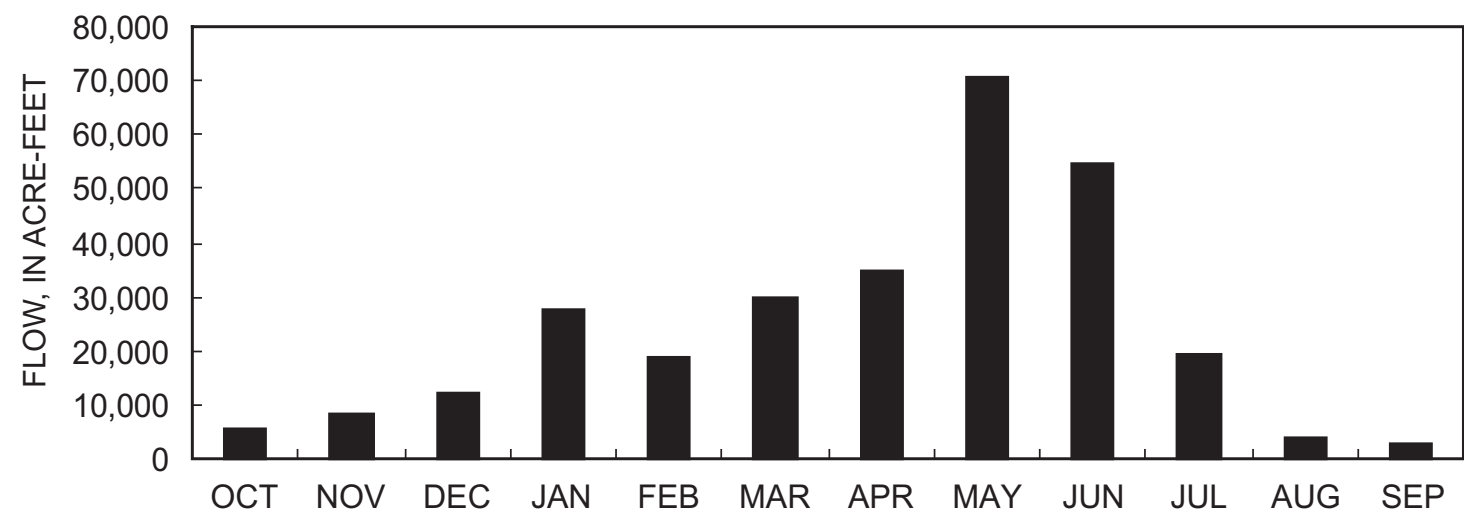

Appendix. Computed and estimated mean monthly flow for gaged and ungaged perennial streams tributary to Carson Valley, 1990-2002-Continued. 